\title{
Establishing Miscanthus, Production of Biomass, and Application to Contaminated Sites
}

\author{
Lawrence C. Davis, Valentina Pidlisnyuk, Aigerim Mamirova, \\ Pavlo Shapoval, and Tatyana Stefanovska
}

\begin{abstract}
The establishment of vegetation on sites with contamination to improve soil quality, reduce risk, and produce a biomass product depends on many local conditions. Site characterization results, remediation goals, local markets for biomass products, soil properties, climate, temperature, annual and seasonal precipitation, past experience at similar sites, and availability of soil amendments are some aspects to consider. This chapter addresses the establishment of Miscanthus and its application when growing in contaminated soil. Plant selection and breeding of Miscanthus is reviewed briefly. Water is very important for the establishment of Miscanthus, and issues related to rainfall during the first weeks and months are reviewed. Plant nutrition and soil amendments affect growth and biomass yield. The time of harvest for Miscanthus affects nitrogen use because much more nitrogen is removed if the harvest is in the fall compared to winter harvest. The effects of soil amendments on the fate of contaminants and plant growth are included because the knowledge of how to obtain beneficial results by adding soil amendments has advanced significantly. Improved results have been reported for Miscanthus production when plant growth regulators have been added. Results from recent literature are included.
\end{abstract}

\section{CONTENTS}

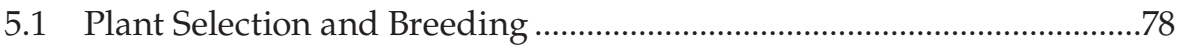

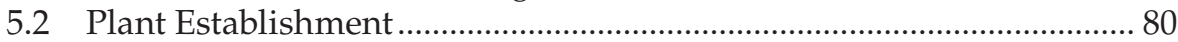

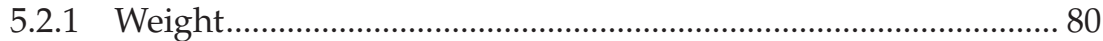

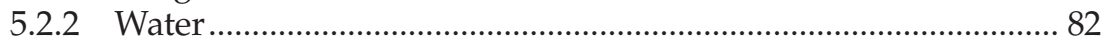

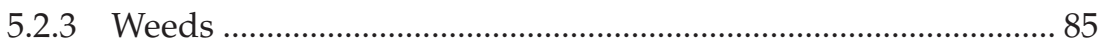

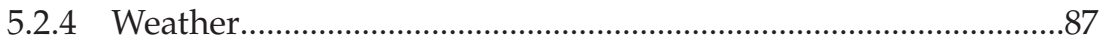




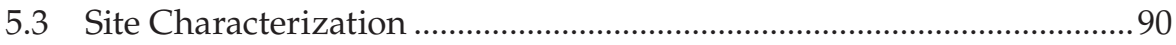

5.4 Plant Nutrition and Supplementation.......................................................99

5.5 Role of Soil Amendments ....................................................................... 94

5.5.1 Impact of Soil Amendments on the Phytoremediation of Soil Contaminated by Organic Substances...................................95

5.5.2 Impact of Soil Amendments on Miscanthus Production in Postmilitary Soil............................................................................... 97

5.5.3 Impact of Soil Amendments on Miscanthus Biomass Production in Contaminated Postmining Soil ............................. 98

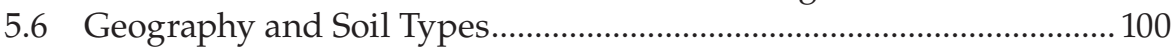

5.7 Role of Plant Growth Regulators in Production of M. × giganteus ..... 102

5.7.1 Lab Research on Impact of PGRs on Phytoremediation with Biomass Production Using Soils from Military Sites Contaminated with Trace Elements.

5.7.2 Field Research on Impact of PGRs on Biomass Parameters of $M . \times$ giganteus during Field Production on the Marginal and Slightly Contaminated Lands ................................................. 104

\subsection{Plant Selection and Breeding}

The cultivar (CV) of Miscanthus $\times$ giganteus (M. $\times$ giganteus) that is used in most studies in the US and many places in Europe is a sterile triploid hybrid of diploid M. sinensis (receiving 1n) and tetraploid M. sacchariflorus (receiving 2n) but with some additional ancestral contribution from M. sinensis (Mitros et al., 2020). It was brought from Japan to Europe by 1930 and sold as a decorative plant until the 1980s when it was promoted, initially in Denmark, as a potential source of biomass (Nielsen, 1990; Pude, 2008). The most widely grown clone in the US was derived from material at the Chicago Botanical Garden and later designated as the Illinois clone. A CV named "Freedom" developed at University of Mississippi from a USDA germplasm collection appears to have essentially the same genotype. A strain obtained by K-State from Bluemel Nursery in 2007 is actually tetraploid M. sacchariflorus. Below it is identified as M. sacchariflorus Bluemel. Material obtained from Bluemel in 1987 and grown at the Minnesota Arboretum in Minneapolis appears identical in observable phenotype, to the Illinois clone of $M$. $\times$ giganteus obtained from Maple River Farms of Owosso, Michigan in 2018 (Davis L. personal observation). The Bluemel Nursery website states that Bluemel obtained his original M. x giganteus material in Europe (Switzerland) in 1960. Thus, we are working with a very narrow genetic base and there is no reason to think that we have a best widely adapted hybrid. 
Some groups have attempted to improve performance by making triploid or tetraploid hybrids of the two above-mentioned species, or by development of selections from either of the parental species for desirable traits. The parental species have relatively wide distributions within East Asia and one can find a wide range of phenotypes with different winter hardiness, daylength sensitivity of flowering, and other important characteristics. Kalinina et al. (2017) reported in detail a program to test multiple germplasms, plus some new crosses, with $M . \times$ giganteus for a reference at multiple sites over a wide range of climatic conditions. Results varied greatly over both years of study, and sites, across Europe from Wales to Russia and Turkey. One triploid hybrid M. × giganteus, "Nagara" bred in Europe by M. Deuter, has been used to some extent in North America but its expected winter hardiness, observed in Urbana, IL (Dong et al., 2019), has not proved out in practice in Ontario, Canada (Sage et al., 2015).

There are several major practical challenges with managing Miscanthus hybrids. One is concern for potential invasiveness of new fertile lines. Selfincompatibility may reduce problems with a single clone, but it is a hazard of seed-grown hybrids. Both of the parental species of M. x giganteus are classified as invasive in some states within the US. That does not mean that they are prohibited, but it reduces their acceptability for widespread distribution and growth, because they may become seriously invasive under some climatic conditions.

Further, in the US there are not mandates for use of carbon neutral strategies unlike in Europe (Clifton-Brown et al., 2017) so that the biofuels market is not good. Ethanol from maize grain is the largest such biofuel and cellulosic, derived from fermentation of cellulose, are unable to compete economically. There is a small market for the direct use of M. x giganteus as fuel, animal bedding, or dietary fiber, but that is satisfied by already available M. x giganteus materials (Moberly Monitor, 2017; UIFM, 2020). The situation is quite different in Europe, so that some large breeding programs continue there.

An excellent review of the longest continuous breeding program, based in Wales, is described by Clifton-Brown et al. (2019). Four tracks of breeding strategy were used to make most rapid progress with a perennial crop, with a goal of identifying a seed-based production plan, rather than clonal propagation as used with $M$. x giganteus. High yield, cold tolerance, drought tolerance, climatic adaptability over a wide geographic area were among the many characteristics being searched for in progeny of thousands of possible crosses from a starting point of 240 genotypes.

A large practical concern in breeding and selection is for propagation and establishment from seed (Xue et al., 2015). Miscanthus seeds are quite small and the plantlets do not become competitive with agricultural weeds until after at least a season's growth. They are also very sensitive to drought 
immediately after planting, or in the following months (Anderson et al., 2015). These factors mean that any seed-propagated crop will require intensive care in the first year. This makes it uncompetitive with even the costly propagation of clonal $M . \times$ giganteus, for which methods of propagation have been improved. A single improved clone such as Nagara, which is also a sterile triploid, might be competitive if it has a significant advantage over $M . \times$ giganteus in yield, hardiness, or ease of propagation.

\subsection{Plant Establishment}

For M. × giganteus, good establishment of a productive field can be challenging. It reaches peak production after 2-4 years and may last in excess of two decades, so that doing it right the first time is expected to pay off. It is not inexpensive to do correctly.

Four critical factors for success are weight (of the propagule); water (to promote root growth); weeds (which must be controlled); weather (which cannot be controlled). Anderson et al. (2011) provide a good example for one specific region of the US where production of biomass approaches its maximum.

\subsubsection{Weight}

It has been observed that for direct planting in a well tilled field, likelihood of success in establishment increases with propagule weight. Typically, dormant rhizomes are purchased/provided with a weight of less than 25-30 g. Success is much higher when they weigh at least $60 \mathrm{~g}$ (Pyter et al., 2010). Preparation costs per propagule, which includes number that can be obtained per unit area of nursery, amount of material to be dug, sorted, and packed, and shipping weight charges, become issues as mass per propagule increases (Figure 5.1).

An alternative which in some settings can reduce costs is using stem buds for propagation in a winter nursery in a warm climate/greenhouse, and then shipment of the actively growing plants, commonly called plugs, to the planting sites. This has been successful in Iowa, USA (Boersma \& Heaton, 2012, 2014a, b). For large-scale biomass production the University of Iowa contracted with a commercial plant propagation company to grow small individual plants during winter, prepared to ship at the appropriate planting time in late April. Each stem from a rhizome can yield about five bud plants, from the most basal, commonly underground, buds, and each $25 \mathrm{~g}$ propagule may yield two shoots which allows a ten-fold more rapid increase of plants than simply using rhizome pieces from a second or third year field 
(a)

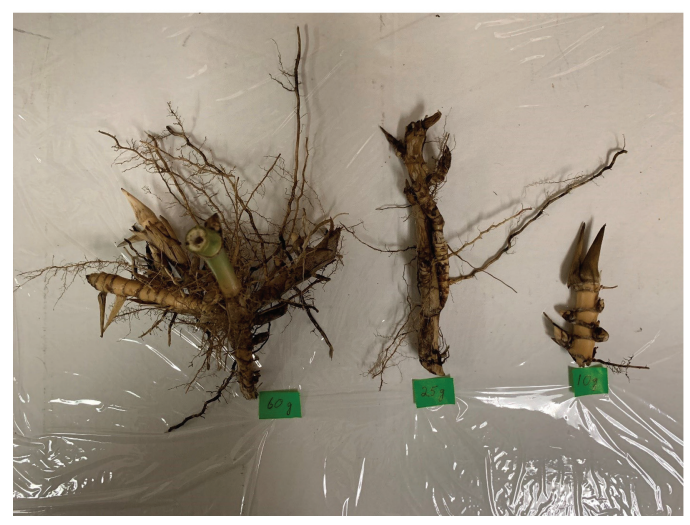

(b)

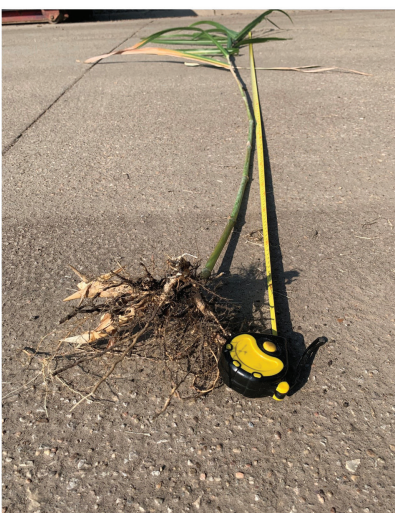

FIGURE 5.1

(a) Three sizes of rhizome piece used for propagation, with fresh weights of about 10, 25, and $50 \mathrm{~g}$. The number of active shoot buds and total reserves is approximately proportional to size. Terminal buds are most active, a kind of apical dominance. The $10 \mathrm{~g}$ pieces are suitable for planting in an intensively managed nursery to produce larger propagules for the next year. The $25 \mathrm{~g}$ piece is of a size typically used for planting. The $50 \mathrm{~g}$ piece is at the minimum of preferred size for a high percentage of successful establishment. It possesses multiple potential shoots at rhizome tips. (b) An ideal propagule, found at the base of a $10 \mathrm{ft}$ tiller, with three distinct rhizomes attached, each of which will grow one strong tiller in the following spring and total weight $>60 \mathrm{~g}$. Such good materials are found at the perimeter of 2- and 3-year-old clumps. Older interior rhizomes are less effective, less vigorous.

of M. x giganteus (Boersma and Heaton, 2014a, b). However, often the costs of this mode of stem and rhizome bud propagation exceed that of using rhizomes directly. Micropropagation was found by Kołodziej et al. (2016) to be more expensive in southeast Poland than use of rhizomes, in part because of poor plantlet survival in field conditions $(\sim 80 \%)$ and the need for replacement plants, but also because the price of rhizomes is relatively lower by a factor of $2-3$. For new CVs, in vitro micropropagation may be worthwhile but it is costlier than either of the above techniques according to Kołodziej et al. (2016).

Comparing rhizome to plantlet propagation with M. x giganteus, Ouattara et al. (2020) tested at six diverse sites in northern and central France followed over 6 years. They found that the rhizomes were less effective for both establishments in year 1 and regrowth in year 2. Establishment was $77 \%$ and regrowth was $86 \%$ compared to $87 \%$ and $94 \%$ for the plantlets from small rhizomes $(\sim 10 \mathrm{~g})$ or stem buds. By comparison seed-grown $M$. sinensis (not directly field seeded but started as plantlets, mixed genotypes) gave high establishment and regrowth, the same as $M$. x giganteus plantlets. M. sinensis had lower yields than $M$. x giganteus over all years, but less year to year variability.

A significant hindrance to direct sowing of Miscanthus seed is allelopathy. Awty-Carroll et al. (2020) documented this problem and identified a complex 
mixture of extractables present in seed including proanthocyanidins and vanillic acid. This makes it difficult to use seed clusters to enhance stands. In controlled competition there appeared to be root competition and it was also observed in field scale that shoot competition was a problem. Thus, when using direct seeding, it proved a challenge to obtain good stands.

The relative price and success of rhizome vs plantlet propagation seem to differ between situations and countries. Much of the variation in success may depend on summer water and winter weather. Overplanting by $25 \%-50 \%$ may be an economically viable alternative to assure an adequate stand (Boersma \& Heaton, 2014a).

\subsubsection{Water}

Adequate water is essential to establish growth of rhizomes. Available water is decreasing in many areas while being found in excess in others. Caslin et al. (2011) report that soil moisture must be at least $40 \%$ of field capacity at planting. The rhizomes desiccate rapidly when kept at ambient temperature without water. Drought at this stage is fatal. If rain is insufficient, supplemental water is necessary. Providing supplemental water to 1 ha of $M$. x giganteus $(>10,000$ plants) can be costly. Drip irrigation would require $1.1 \mathrm{~km}$ of drip tubing with nozzles at plant spacing (up to $1 \mathrm{~m}$ apart), plus additional fittings. With drip irrigation, watering needed will depend on the soil water-holding capacity within a zone comprising several liters surrounding each rhizome. The equivalent of $10 \mathrm{~cm}$ depth of water in an area $15 \mathrm{~cm}$ in radius $(7 \mathrm{~L})$ will wet soil to a depth of about $30 \mathrm{~cm}$. This uses $70 \mathrm{~m}^{3}$ of water for 10,000 plants. To supply each plant with a supplemental $10 \mathrm{~cm}$ water uses $1000 \mathrm{~m}^{3}$ of water if using sprinkler irrigation.

For a first-year crop, drip irrigation can allow large savings if water is expensive. During peak growth later in the establishment year, water use may be greater than $5 \mathrm{~cm}$ depth $\mathrm{wk}^{-1}$. There must be sufficient supply to have significant percolation of water to depths greater than the root depth during establishment, to encourage their downward growth. Roots of $M$. x giganteus are reported to reach depths of $>2 \mathrm{~m}$, though the large majority of roots, when water is available, remain much closer to the surface. Rhizomes of $M$. x giganteus are usually within the top $15 \mathrm{~cm}$ (Sage et al., 2015) (Figure 5.2).

In the study described by Kalinina et al. (2017), drip irrigation was used in Turkey during second to fourth years, with sufficient irrigation $(23 \mathrm{~cm}$ in year 2) added to nearly match the potential evapotranspiration. The amount of irrigation used in year 1 was not stated but it was enough to result in rapid growth of the plants, so that yields, averaged over all trialed CVs that were better in the first year than other sites, were also better in the second year $\left(>10 \mathrm{tha}^{-1}\right)$, though not for lack of water in the more temperate settings of other sites. The longer, warmer growing season in Turkey may have been largely responsible for higher production. See discussion below about geography of factors for Miscanthus growth. 


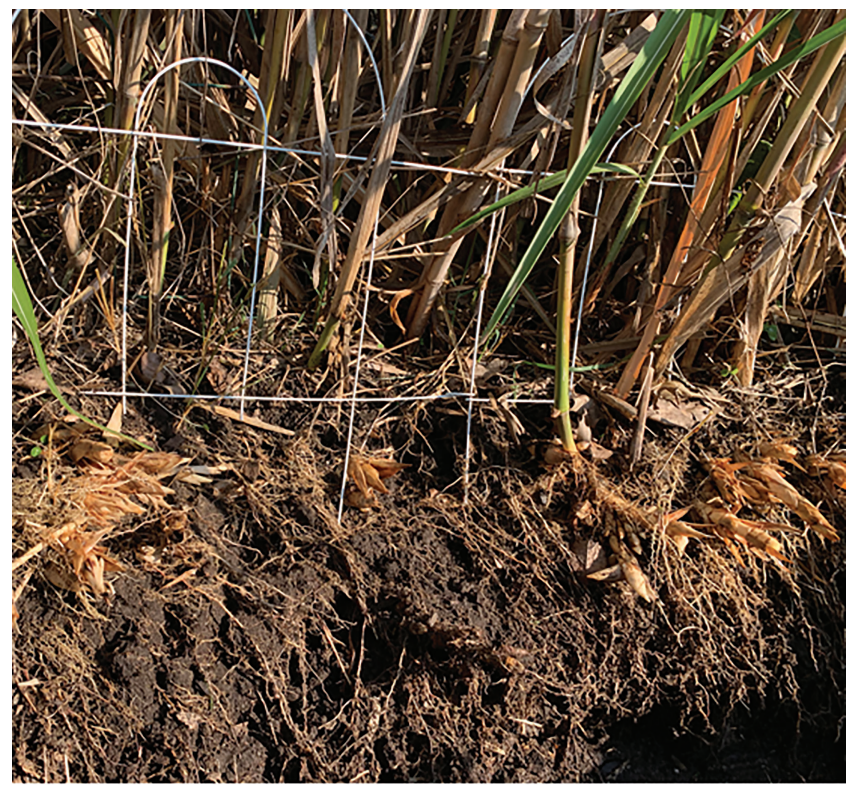

FIGURE 5.2

Excavated section at the edge of a plot of $M . \times$ giganteus showing tillers arising from ground with prominent rhizomes, long thin exploratory roots, and short highly branched roots that explore the soil for water and nutrients. The length of roots penetrating into deeper soil depends on water availability and soil porosity. The green tiller at center right is shown as Figure 5.1b, a perfect propagule.

When the canopy closes and the crop matures to optimum production, after a minimum of 2-3 years but sometimes near a decade, water use is at least $200 \mathrm{~L} \mathrm{~kg}^{-1}$ aboveground dry matter accumulation (Clifton-Brown \& Lewandowski, 2000; Mantineo et al., 2009). In dry climates, more water is lost than in humid ones. Hot and windy conditions also increase water losses. The highest reported total dry matter production may reach $40 \mathrm{t} \mathrm{ha}^{-1}$ which requires a minimum of $0.8 \mathrm{~m}$ water during the active growing season. This usually implies a total rainfall or irrigation of $>1 \mathrm{~m}_{\text {year }}{ }^{-1}$. Moisture deficit explained $70 \%$ of the variance in M. x giganteus yield, at Rothamstead, UK, which had the largest available data set (Richter et al., 2008) with yields that ranged from 5 to $18 \mathrm{tha}^{-1}$. There was an average of $12.8 \mathrm{t} \mathrm{ha}^{-1}$ across $14 \mathrm{UK}$ sites over 3 years.

There are few quantitative reports on minimum water requirements for successful growth of $M$. x giganteus in relation to different climates. In southern Oklahoma (34.2 N latitude) yields are consistently low because summer rainfall is insufficient (Kering et al., 2012). Temperatures are high, probably too high, and skies are clear. Fully irrigated maize grown somewhat further north in southwest Kansas ( $38 \mathrm{~N}$ latitude), with some of the highest solar availability in the nation, produces yields to $19 \mathrm{t} \mathrm{ha}^{-1}$ grain and near $38 \mathrm{t} \mathrm{ha}^{-1}$ total dry matter (KCYCW, 2019). Comparable maize grain yields are obtained 
in southern Nebraska ( 41 N latitude) at over $17 \mathrm{t} \mathrm{ha}^{-1}$, near $34 \mathrm{t} \mathrm{ha}^{-1}$ biomass, with contest winners exceeding $19 \mathrm{t} \mathrm{ha}^{-1}$ of grain (NCGA, 2019).

Miscanthus yields may be higher in temperate zones of southern Europe, e.g., Croatia northward ( 45 N latitude), where longer daylength promotes summer growth and delays flowering of $M$. $\times$ giganteus if water is not limiting. On the other hand, yields of $M$. x giganteus in the US are not generally higher in southern states, below $\sim 30 \mathrm{~N}$ latitude, where daylength is shorter sooner, even when rainfall and soil fertility are not limiting. Lee et al. (2018) provide results for maintenance stages of $M$. $\times$ giganteus production in comparison with other biomass energy crops (selected cultivars of switchgrass, sorghum, and sugarcane) in the U.S. Rainfall, and in some cases fertilizer application, affected productivity at most sites, after successful establishment. Productivity was most variable in Mead Nebraska ( 41.2 N latitude), ranging from 15 to $35 \mathrm{Mg} \mathrm{ha}^{-1}$, while other sites had intermediate but more stable yields. This was primarily a function of variable rainfall in Nebraska plus a variable long growing season.

Lee et al. (2017) reported a strong interaction of water availability and $\mathrm{N}$ fertilization at Urbana, IL ( 40 N latitude). For an established study (from 2008 to 2009) yields declined in a droughted summer of 2012 for the unfertilized plots while remaining relatively high and stable with $\mathrm{N}$ fertilization at $60 \mathrm{~kg}$ $\mathrm{ha}^{-1}$ year $^{-1}$. Plots were $10 \times 10 \mathrm{~m}$ and 100 plants, with four replicates of each treatment. Water availability was extremely reduced, $68 \%$ and $90 \%$ below historic averages over 2 months, June and July in 2012, August and September in 2013. Yields for $0 \mathrm{~kg} \mathrm{ha}^{-1}$ added $\mathrm{N}$ vs $60 \mathrm{~kg} \mathrm{ha}^{-1}$ were: in 2011, 15.9 vs $23.3 \mathrm{Mg}$ $\mathrm{kg} \mathrm{ha}^{-1}$; in 2012, 11.6 vs 24.8 ; in $2013,15.3$ vs 28.8 ; in $2014,8.5$ vs 25.9 . The low rainfall in 2013 continued throughout the remainder of the year at $<1 / 2$ of the 30 -year average ( $28 \mathrm{vs} 61 \mathrm{~cm}$ ) for the latter half of the year. Although rainfall in 2014 was above average, the unfertilized plot may have been unable to take advantage of that abundance. Averaged over the 4 years, yield in the fertilized plots was double that of the unfertilized (25.5 vs $12.8 \mathrm{Mg} \mathrm{ha}^{-1}$ year $^{-1}$ ).

It should be noted, however, that Lee et al. (2018) reported rather different yield data for experiments with the same treatment design at the same, or a very nearby location. For instance, in 2014 the unfertilized plots yielded the same as in 2013, while in 2012 yields of both unfertilized and fertilized plots were about half of their respective yields in 2013. Neither paper offers any comment on the large apparent differences. Sampling of biomass yield seems to have been done differently in the two studies. Lee et al. (2017) used five $1 \mathrm{~m}^{2}$ quadrats per plot while Lee et al. (2018) used one $4 \mathrm{~m}^{2}$ sample at the center of the $10 \times 10 \mathrm{~m}$ plot. Even with such a large sample, some replicates in some years varied from others within a treatment, by more than two-fold as shown in their supplemental data. These results indicate that interpreting Miscanthus yields in terms of known variables such as rainfall is challenging.

In a dry summer Mediterranean climate (Sicily) restoring 25\% ( 15 cm) or $75 \%(\sim 45 \mathrm{~cm})$ potential evapotranspiration water by irrigation increased yields of both Arundo donax and M. xgiganteus energy crops studied by 
Mantineo et al. (2009). The common name of Arundo donax is giant cane or giant reed, and it bears some similarity to M. x giganteus in adaptability and productivity, as discussed below. Even when irrigation was stopped in the fourth year of study, M. × giganteus yielded over $27 \mathrm{Mg} \mathrm{ha}^{-1}$. Yield decreased somewhat in the fifth year with no irrigation. Significant winter rainfall must have been stored in the soil column, although soil water capacity was reported as $\sim 10 \mathrm{~cm}$ in the top $0.8 \mathrm{~m}$ of total $1.2 \mathrm{~m}$ soil depth.

Successful M. x giganteus establishment in this Mediterranean climate was absolutely dependent on irrigation because of very limited summer rainfall (Mantineo et al., 2009). Cosentino et al. (2007) had earlier measured Water Use Efficiency (WUE) for M. x giganteus grown with limited irrigation in the same environment and found it was above $4.5-4.8 \mathrm{~g} \mathrm{~L}^{-1}$ aboveground dry matter production in consecutive years. They noted that the WUE declined as more water was provided to $\sim 2.5$ and $3.5 \mathrm{~g} \mathrm{~L}^{-1}$. The reported numbers are consistent with the work of Clifton-Brown \& Lewandowski (2000) in a greenhouse experiment where water amounts are more easily measured. The work of Cosentino et al. (2007) and Mantineo et al. (2009) suggests that M. Xgiganteus can produce high yields with less water than most crops.

In no year does the $M$. x giganteus WUE reach the WUE of $A$. donax in the same location, which was above $4 \mathrm{~g} \mathrm{~L}^{-1}$ beginning with the second year. The authors note that $A$. donax did not go totally dormant in winter, unlike M. $x$ giganteus, and so may it make better use of available water in winter. Of course, in colder climates such advantage is not available. The aboveground vegetation of $A$. donax like that of $M$. x giganteus is frost sensitive, though perhaps not so much so. Below-ground rhizomes are killed at about $-5^{\circ} \mathrm{C}$ for 24 hours, a bit more tolerant than M. x giganteus (Pompeiano et al., 2015).

It is clear from the above studies, and general knowledge of crop physiology, that water-holding capacity of soil, in addition to total applied water, and deep roots are all critical for maximizing yield when dependent on rainfall. One recent study from Ukraine (Doronin et al., 2019) shows that the use of water-retaining materials can benefit rhizome development when that is the goal, as in the preparation of large rhizomes for transplanting. Water-holding materials can allow for longer survival in transitory droughts and are widely used in potting materials for planters that are intermittently watered. This might not be economical for field-scale production but could benefit nursery preparation of planting materials.

\subsubsection{Weeds}

Detailed studies of herbicide tolerance of $M$. x giganteus were done by Eric Anderson for his M.S. degree at University of Illinois (2010). Tolerance to broad-leaf herbicides (mainly auxin analogs) was the same as for maize, as expected. Tolerance of wider-spectrum herbicides and of those designed for control of grassy weeds were also reported. A more extensive greenhouse study by Smith et al. (2015a) considered 22 PRE- and 22 POST-planting 
herbicides with several energy crops. They noted that M. x giganteus from rhizomes was more tolerant than seedlings of hybrid Miscanthus.

Careful field preparation and use of a broad spectrum, short-lived herbicide such as glyphosate has been found to be important for obtaining good vigorous M. x giganteus stands in the US and UK (Caslin et al., 2011; USDA/ NRCS, 2011). For regulatory reasons we cannot make specific recommendations for U.S. registered herbicides in Europe or Asia, and vice versa. Song et al. (2016) confirm the essential need for strong weed control and provide a useful example of the range of herbicides that are effective with M. sacchariflorus in Korea. Similar results are described for M. x giganteus (Roik et al., 2019).

Management of weeds after M. x giganteus has begun growing requires special care to not damage the plants. Tillage methods can only be used between rows, carefully avoiding close approach to the plants themselves. Herbicide application must be under strictly defined conditions of temperature, soil moisture, and wind speed to meet regulatory requirements and avoid damaging stressed plants. Because $M . \times$ giganteus is a single clone; no genetically modified (GM) form of the plant is available to make use of resistance to specific herbicides, unlike maize resistant to glyphosate and dicamba.

A comparison study in Kentucky and Virginia by Smith et al. (2015b) showed that weed competition in those two locations, on ground previously in no-till rotations with winter cover-cropping, was not a significant obstacle for several energy crops including M. x giganteus CVs Illinois, Nagara, and (tetraploid fertile) PowerCane. The main difference between this study and the earlier work in Illinois was that the soils of Illinois are richer in $\mathrm{N}$, having been in crop rotations requiring high $\mathrm{N}$ levels, mainly maize. They may also have larger seed banks of weedy species.

Our first effort to grow Miscanthus in the field began May 1, 2015, at Ft. Riley, KS ( 39 N latitude). It made use of large propagules of the M. $\times$ giganteus Bluemel strain kept 1 month or 13 months at $4^{\circ} \mathrm{C}$, and smaller plantlets grown under lights during the previous summer, autumn, and winter. Those were grown under several conditions including soil from the planting site, with or without fertilizer; perlite, or perlite plus vermiculite both with $1 / 2$ strength Hoagland's solution. Rhizomes (60-90 g) harvested from larger potted ( 12 L) plants stored cold 6 or 18 months, and freshly harvested (from a field site) actively growing rhizomes were also tested. Some plantlets were grown up and then stored 5 months in cold.

The site was grassland, with alfalfa, normally mowed several times per year. All vegetation was cut to $\sim 1-2 \mathrm{~cm}$ with a "weedeater" and propagules were planted at $45 \mathrm{~cm}$ intervals in 11 rows, spaced $45 \mathrm{~cm}$ apart. Including border edges, the plot was $6 \times 6 \mathrm{~m}$. Fertilizer, tillage, and herbicide treatments were avoided. Every Miscanthus plant was marked with a bamboo stick. Rain was abundant, with three intervals of $>10 \mathrm{~cm}$ rain, after 3 days, during the following 3 weeks and again during 2 weeks. Weeds were trimmed down to 
$<10 \mathrm{~cm}$ on two occasions, June 1 and June 18. Rain was adequate through the remainder of the season. No further weed control was used.

Survival was recorded on May 5, 2016, when plants had emerged from winter dormancy. The plantlets stored cold in perlite or perlite + vermiculite and knocked off at planting, had as fraction of survivors, 7/11; with mixture left on, 8/11; small rhizome propagules, or actively growing rhizomes $9 / 11$; all other treatments $11 / 11$. Some of the more vigorous plants in one border row had extended runner rhizomes over $50 \mathrm{~cm}$ out into the surrounding area. In December 2016 this plot had a biomass of $8.0 \pm 1.9 \mathrm{tha}^{-1}(\mathrm{~N}=$ three samples of $0.81 \mathrm{~m}^{2}$ ) comparable to the 2016 year 1 yield of the study by Alasmary (2020), which was done immediately adjacent to this trial plot.

\subsubsection{Weather}

While climate change is a long-term transition that may alter the optimum growth regions for $M . x$ giganteus, changeable weather is the present challenge. Average winters have become warmer over much of the US, but occasional sudden changes are much more damaging to $M$. x giganteus. Late spring frosts or sudden early autumn frosts can have large consequences (Kaiser and Sacks, 2015). In springtime, energy expended in sending forth shoots is lost when a sudden freeze severely injures them.

A major collaborative study of Miscanthus production and efforts to model its productivity in the US (Lee et al., 2018) has 58 authors. It was initiated in 2008 and compared Miscanthus with several other potential bioenergy sources including switchgrass, forage sorghum, "energycane" which is a version of sugarcane, and mixed grasses. Weather and geography were obvious variables. The duration and locations of trials for the different crops varied. For Miscanthus a 6-year study was done in five locations. At two initial locations, in Illinois and Indiana, there was high winter mortality of the transplants which had been started from $\sim 25 \mathrm{~g}$ propagules in a greenhouse prior to planting in June/July 2008 (rather late). In Illinois 75\% of plants were lost. The severely damaged Indiana site was replaced by one in the Virginia Piedmont in 2010. That site is climatically milder but with soils and terrain generally less suited to annual row crops.

We observed signs of significant prior frost damage on early emerging M. sacchariflorus Bluemel when we were planting on May 2, 2017, 2 weeks after the expected date of the last killing frost in our climate. The year-old plants in the study of Alasmary (2020) were $\sim 50 \mathrm{~cm}$ tall by May 2, showing damaged foliage. A 2-year-old (2015) trial plot which had not been harvested the previous autumn had much shorter plants with far less damage (personal observation). Residual vegetation presumably delayed soil warming and shoot emergence.

Sudden fall frosts are reported to damage first year M. x giganteus in Illinois because the plants tend to remain green longer during their first year (Boersma et al., 2015). This frost damage in turn reduces the translocation of 
nutrients back to the rhizome (Aurangzaib, 2012). Sage et al. (2015) observed and quantified a similar effect on a new triploid M. x giganteus hybrid (Nagara) in Ontario, Canada. In this instance 3/4 of the leaf $\mathrm{N}$ failed to translocate. Similar effects may be observed for other nutrients.

During winters, especially the first winter, M. $x$ giganteus is vulnerable to freezing damage. When soil temperature drops below $-3^{\circ} \mathrm{C}$ to $-5^{\circ} \mathrm{C}$ at a depth of 4-10 cm, rhizomes are killed (Dong et al., 2019; Heaton et al., 2010). Insulation of the planting with straw, dropped foliage, or other means may be critical for good establishment in places where such cold is likely. In a long-term study described by Maughan et al. (2012) and Lee et al. (2017), 75\% of a 2008 summer planting of potted, actively growing rhizomes was lost in the first winter. These had been greenhouse grown from $25 \mathrm{~g}$ rhizomes in $9 \times 9 \times 12 \mathrm{~cm}$ pots so they were much larger than typical plantlets, but were planted rather late in mid-July. The missing plants were replaced in 2009 (Maughan et al., 2012).

A fall planting of M. $x$ giganteus $\sim 25 \mathrm{~g}$ rhizomes at Mimon, Czech Republic, was fully destroyed by an 8-day February-March period of air minimum temperatures at $-10^{\circ} \mathrm{C}$ to $-18^{\circ} \mathrm{C}$ and maxima below 0 . Soil temperatures were not determined. Only $1 / 10$ of a previous spring planting in that same location survived (Nebeska D. personal observation).

Kucharik et al. (2013) developed a predictive model for likelihood of winter loss, based on a 30-year climate record across the Midwest US. The effect of insulation of the crop by straw and leaf matter at various depths was also calculated. A layer of $5 \mathrm{~cm}$ gave significant protection in many regions but the northern portions of several states near the Canadian border ( $\sim 49 \mathrm{~N}$ latitude) had a 50\% likelihood of losses even with protection. So far as we are aware no comparable model has been generated for Europe, although it is feasible to do so. Somewhat surprisingly, in the studies described by Kalinina et al. (2017), M. xgiganteus survived winter even in the vicinity of Moscow, Russia ( 55.75 $\mathrm{N}$ latitude), because soil temperatures never dropped below $0^{\circ} \mathrm{C}$ in the winter of 2012-2013.

Seasonal droughts of varying magnitude have a strong negative effect on biomass yield, when irrigation is unavailable. Kering et al. (2012) described this effect in southern Oklahoma where half of carefully pot-grown M. $\times$ giganteus plants died during the 2 months of 2008 following transplantation to a field site, while other biomass grasses had high survival. Biomass yield of the M. x giganteus never approached that of the other crops over the study period even though precipitation returned from $58 \mathrm{~cm}$ in 2008 to near average $97 \mathrm{~cm}_{\text {year-1 }}^{-1}$ value in the second and third years $(130$ and $91 \mathrm{~cm}$, respectively). In Eastern Ukraine, a planting of M. x giganteus failed in 2017 when summer rainfall dropped from an average of 7 to only $1 \mathrm{~cm}$ during July although the annual total was close to the average $45 \mathrm{~cm}$ (Stefanovska T. personal observation).

Failures of timely rain following a 2017 planting at Ft. Riley, Kansas ( $\sim 39 \mathrm{~N}$ latitude), resulted in loss of $\sim 1 / 4$ of the M. sacchariflorus Bluemel 
(Davis L. personal observation) contrasting with zero losses in 2016 with abundant rain (Alasmary, 2020). During 2018 a direct comparison was done with $M . \times$ giganteus and the $M$. sacchariflorus Bluemel strains both at the Ft. Riley site and at the Kansas State University North Farm site ( $39.2 \mathrm{~N}$ latitude). At the former location there was a failure of rains over several weeks, and nearly total loss (>90\%) of both CVs (two replicates each of 16 plants planted on $45 \mathrm{~cm}$ centers). At the North Farm where some supplemental irrigation was available, four replicate plots each of 36 plants grown on $45 \mathrm{~cm}$ centers were compared. Survival of the Bluemel strain was much higher $(\sim 3 / 4)$ than that of $M$. $x$ giganteus $(<1 / 2)$ perhaps because larger propagules of 60-90 g vs $25 \mathrm{~g}$ were available. Even in autumn 2020, the $M$. x giganteus plants remain as individual clumps of $<50 \mathrm{~cm}$ diameter, while the Bluemel strain plants, with no supplemental irrigation since early summer 2017, are invading the entire planting (Davis L. personal observation). This is consistent with observations mentioned above where it sometimes takes more than 4 years to reach maximum productivity which depends on total number of stems (tillers) and number of leaves on each (Lee et al., 2017) (Figures 5.3 and 5.4).

In southeastern Kansas the Mound Valley experiment station ( $37.2 \mathrm{~N}$ latitude) had an average yield of $11.3 \mathrm{t} \mathrm{ha}^{-1}$ for the third to fifth years of growing Illinois and "Freedom" M. x giganteus CVs (which are genetically near identical M. x giganteus). There was no correlation of yield to annual rainfall amounts of 91, 130, and $104 \mathrm{~cm}$ in years 3-5 (2014-2016). In the establishment year (2012) a significant fraction of the plants failed despite occasional irrigation. These were replaced in 2013 and the 2013 yield was about $5.4 \mathrm{t} \mathrm{ha}^{-1}$. In

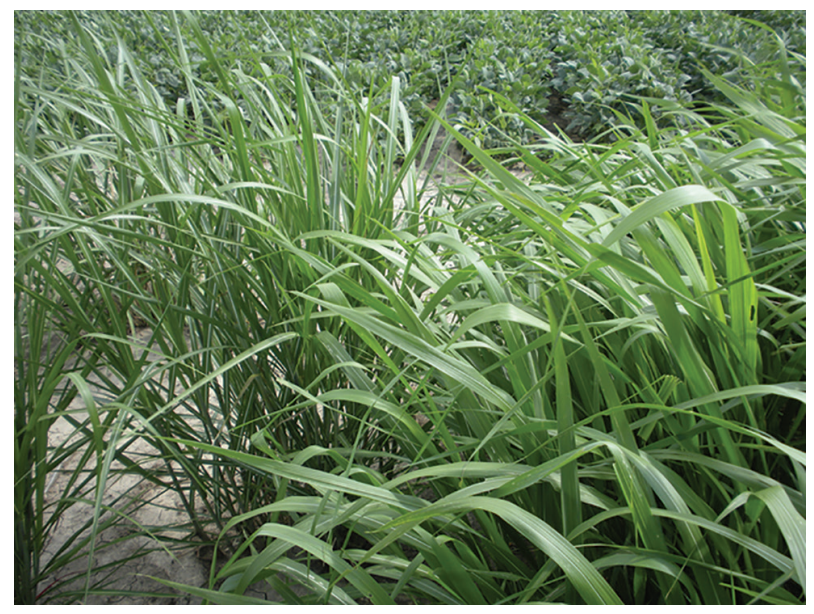

FIGURE 5.3

Comparison of characteristic leaf form of $M$. sacchariflorus (lower right), with $M$. x giganteus (upper left) on September 11, 2018 prior to flowering of the latter. Leaves of M. sacchariflorus are wider than those of $M$. x giganteus. 


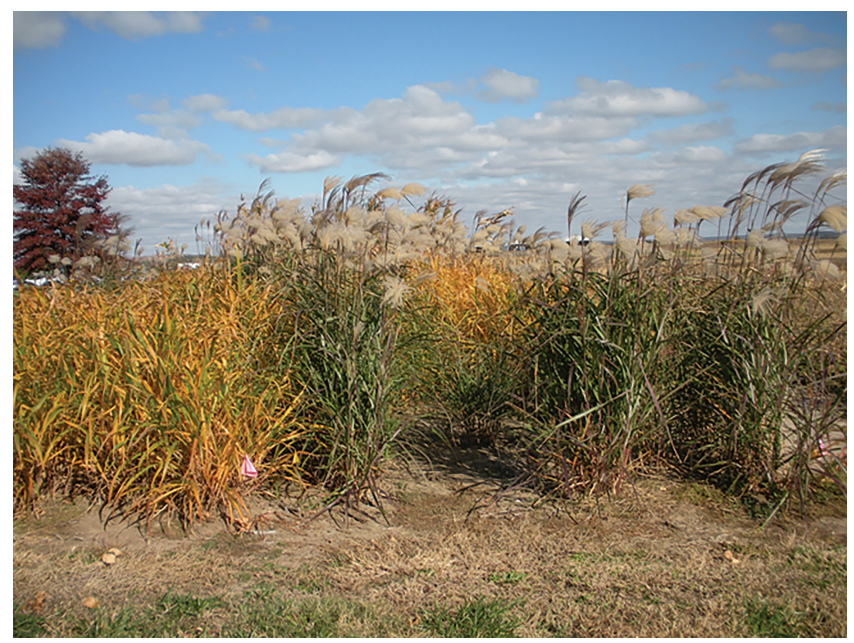

\section{FIGURE 5.4}

Direct comparison of growth habit of M. x giganteus (front right) and M. sacchariflorus Bluemel (left, and behind) at the North Farm site, K-State, KS, in the fall of 2018. The M. x giganteus was obtained from Maple River Farms and planted on May 1, 2018. It produced flowers in early October. (See Figure 5.3 for a photo taken in mid-September.) The flowering $M$. x giganteus stands out above the $M$. sacchariflorus allowing easy visualization of the first-year clumps. The M. sacchariflorus is also senescing. View is from south to north showing the two series of four plots in a checkerboard pattern. Gaps in the M. x giganteus plot are where propagules failed. Photo taken in mid-October.

that year 2 summer drought periods, each of over 1-month duration, may have reduced the second-year yield although the overall annual precipitation was $88 \mathrm{~cm}$. Alternatively, the crop may not have closed canopy to fully exploit resources (Moyer, 2017).

\subsection{Site Characterization}

For any site it is essential to characterize basic properties. Unless you intend to do research and know some specific details about previous contamination of the site, it is really just a matter of the standard agronomy questions. What are soil $\mathrm{pH}$, texture (percentage sand, silt, clay), organic $\mathrm{C}$, cation exchange capacity, and available nutrients $(\mathrm{N}, \mathrm{P}, \mathrm{K}$, and micronutrients)? Are there problems of weeds, excess or insufficient water, any hazards from unexploded ordnance? Also very important is whether the site was recently treated with persistent herbicides that could interfere with the establishment of $M$. x giganteus. If the land is marginal but being used for agriculture, it may be important to know the kind of crop being managed in the years prior 
to the establishment of Miscanthus planting. Legumes may supply carryover nitrogen. Long-term grasslands might have relatively few aggressive weeds that are common in highly fertilized crop rotations. Following heavily fertilized crops such as maize, omitting $\mathrm{N}$ fertilizer may help reduce weed growth in the first year.

If there is known contamination, you will need analysis of extractable and bioavailable levels of the contaminants. Do some plants grow successfully on the site now? What type of soil is it - natural, reclaimed after mining, a result of extreme grading as for an airfield, or technosol (something manufactured somehow, such as waste dumps, dredged sediments, or mine wastes, combined with other materials)? Is it a uniform area or heterogeneous, for instance, with many different smaller contaminated areas, as in an abandoned pesticide storage area? Does soil texture changes with depth? Are there known health hazards for workers? Can you have some certainty of access for multiple seasons to establish a harvestable perennial crop?

For a research plot one should do a more detailed investigation in order to later verify changes produced during Miscanthus growth. For instance, to validate claims of successful remediation of organic contaminants it is essential to have good information on the starting concentrations of the contaminants of concern across the site. This means using a systematic regimen of sampling to appropriate depths and with a spacing suitable to the expected variation or heterogeneity of the site. For a large area uniformly contaminated, perhaps 10 samples ha ${ }^{-1}$ is sufficient; for a more heterogeneous site in an area where there are many exposed receptors (people or animals) one may need more than 100 samples ha-1. This is especially important if the contaminants of concern are taken up and stored in Miscanthus because they could spread the exposure beyond the site when harvested and transported, and then processed in some way.

\subsection{Plant Nutrition and Supplementation}

Soil fertility amendments, if any are needed, will vary with the results of initial characterization. These may include mineral or organic fertilizers, or possibly trace elements such as B or Mo. Organic fertility amendments often are animal or treated human wastes which typically contain trace elements. In the US, "biosolids" is a term used to describe the final product of a residential sewage waste treatment plant. They are closely regulated, much more so than animal wastes. Biosolids are often stabilized with additives such as lime or iron. They are high in organic carbon and the $\mathrm{pH}$ is usually near neutral giving efficiency in sorbing metals. Because there is a reasonably high concentration of total $\mathrm{N}$ in such waste $(4 \%-8 \%)$, biosolids often can serve as an adequate $\mathrm{N}$ source for a crop (Evanylo, 2006). Levels of $\mathrm{P}$ and $\mathrm{K}$ are often beneficial to add to the soil, 
but the applied $\mathrm{N}$ rate is generally used in determining the proper amounts to apply (USEPA, 1994). In addition, high iron in biosolids will increase trace element sorption capacity of the receiving soil. High organic matter will contribute to both trace elements and organic contaminant retention. Further, high organic carbon will promote microbial activities, enhancing organic contaminant degradation, and nutrient cycling. Biosolids applications are also limited by concentrations of specific toxic elements (e.g., $\mathrm{As}, \mathrm{Pb}, \mathrm{Cr}, \mathrm{Cd}, \mathrm{Zn}$ ); however, regulated biosolids (such as Class $\mathrm{A}$ and $\mathrm{B}$ biosolids in the USA) contain very low levels of trace elements. The field experiment at Ft. Riley, KS, had one treatment of biosolids in its design (Alasmary, 2020).

Other nutrient amendments of soil might include other sources of organic matter such as composted animal confinement wastes. These are a useful source of $\mathrm{N}, \mathrm{P}, \mathrm{K}$ but in varying amounts depending on the animal source and the diet of the animals, which will be very different for ruminants, nonruminant mammals, and poultry. Waste from nonruminants is often very high in $P$, to the extent that struvite mineral (magnesium ammonium phosphate) can be recovered in large quantities by intentional treatments (Castro-Diaz S., personal communication). In some settings excess P may be the limiting factor for biosolids application. Optimum $\mathrm{pH}$ for Miscanthus growth is about 5.5-8. Acidic soils would benefit by application of lime to raise $\mathrm{pH}$ into this range. Both calcium and magnesium are essential for crop growth. Based on harvested material in winter, Miscanthus biomass removes relatively little $\mathrm{N}, \mathrm{P}$, or $\mathrm{K}$ from soil, about $5 \mathrm{~kg} \mathrm{t}^{-1}$ of $\mathrm{N}, 0.5 \mathrm{~kg} \mathrm{t}^{-1}$ of $\mathrm{P}$, and $7 \mathrm{~kg} \mathrm{t}^{-1}$ of $\mathrm{K}$ (Iqbal et al., 2017). Earlier harvest before leaf fall, nutrient translocation, and rainfall leaching of biomass will remove more, often a lot more. As mentioned above, Nagara CV of $M$. x giganteus was noted to retain $3 / 4$ of the leaf $N$ when injured by fall freezing (Sage et al., 2015). Hence an early harvest may remove $20 \mathrm{~kg} \mathrm{t}^{-1}$.

Very often it has been observed that added $\mathrm{N}$ does not benefit a Miscanthus crop in the planting year. In some situations, added $\mathrm{N}$ is beneficial in later years. As recognized by Lee et al. (2017), some locations receive higher levels of $\mathrm{N}$ deposition from the atmosphere than others do. Places with highdensity animal production may release higher amounts of ammonia to the atmosphere from hydrolysis of urea. At Konza prairie, a relatively "pristine" preserve, near Kansas State University, nitrogen deposition in rainfall and particulates amounted to $\sim 10 \mathrm{~kg} \mathrm{ha}^{-1}$ year-1 over the first 18 years of the 21st century, although there appears to be a downward trend to $<9 \mathrm{~kg} \mathrm{ha}^{-1}$ year $^{-1}$ in the past decade. Lee et al. (2017) suggested that deposition rates were significantly higher in Europe. A reported value of $14 \mathrm{~kg} \mathrm{ha}^{-1}$ year $^{-1}$ for Germany may be found at Schaap et al. (2017). For the UK, the historic trend is downward in this century and reported as about $10 \mathrm{~kg} \mathrm{ha}^{-1}$ year $^{-1}$ in 2010 (Tomlinson et al., 2011). For some regions of the UK deposition rates were at least two-fold higher in the 1990s when early studies of Miscanthus were done. The reported deposition rates could support a yield of several $\mathrm{Mg} \mathrm{ha}^{-1}$ without depleting soil $\mathrm{N}$ at all. This is an example of large geographic 
variability independent of typical climatic rainfall and temperature differences and geographic factors such as latitude and altitude.

Lee et al. (2018) observed quite variable responses across sites and years in the US. Added N at 60 or $120 \mathrm{~kg} \mathrm{ha}^{-1}$ was rarely detrimental, and sometimes beneficial. The work of Lee et al. (2017) in Illinois ( $40 \mathrm{~N}$ latitude) showed that very high yields of biomass were obtained with added $\mathrm{N}$, at rates of 60 and $120 \mathrm{~kg} \mathrm{ha}^{-1}$ year $^{-1}$, but the higher rate gave no improvement over the $60 \mathrm{~kg} \mathrm{ha}^{-1}$ rate. Yields were reasonable in the $0 \mathrm{~N}$ control plots, but averaged half the yield of the N-fertilized plots over years 2011-2014, where drought may have affected yields (see discussion above under water). In other studies, mass balance calculations suggest that the crop may fix atmospheric $\mathrm{N}$ by a symbiotic association (Davis et al., 2010). Bioavailability of adequate P may be decreased at high $\mathrm{pH}$ in soils with abundant calcium. This combination produces calcium hydroxyapatite, which is quite insoluble at $\mathrm{pH} 8$. Miscanthus extracts K efficiently from soil, but it seems to be a common practice to add a small supplement proportional to amounts removed with the crop, especially after several years of harvest.

A significant concern may be overfertilization of Miscanthus, if it is intended for combustion. This is because high $\mathrm{K}$ and high $\mathrm{Cl}$ lead to corrosion and slag formation in the combustion chamber. It has been reported that use of large amounts of biosolids can result in plants taking up excess levels of these elements, far above disagree strongly what is essential for growth, lowering the end use value of the biomass (Kołodziej et al., 2016). Those authors applied "sewage sludge" one time in amounts up to 60 dry matter $t$ $\mathrm{ha}^{-1}$ and observed that peak productivity was reached at about $10-20 \mathrm{t} \mathrm{ha}^{-1}$ in later harvests, but all levels appeared inhibitory in the first year. Nitrogen (total) levels in the biosolids were $7.45 \%$ with relatively high ammonium $\mathrm{N}$ of $2.35 \%$ at the time of application and tilling into $40 \mathrm{~cm}$ depth during the autumn prior to planting Miscanthus. The ammonium presumably volatilized or nitrified over winter. If not, it might be toxic at up to $250 \mathrm{mg} \mathrm{kg}^{-1}$ of the top $40 \mathrm{~cm}$ soil. The cause of first-year inhibition by sewage sludge is unclear, because there were not high concentrations of toxic trace elements or sodium according to data presented by the authors. The $\mathrm{Zn}$ level in the sludge was $1000 \mathrm{mg} \mathrm{kg}^{-1}$, which when applied at $60 \mathrm{Mg} \mathrm{ha}^{-1}$ would increase the $\mathrm{Zn}$ level of soil by only $15 \mathrm{mg} \mathrm{kg}^{-1}$ for the top $\sim 40 \mathrm{~cm}$.

A rather different approach was taken by Dubis et al. (2020) who grew Miscanthus in Poland for 5 years with high applications of mineral fertilizer ( $90 \mathrm{~kg} \mathrm{ha}^{-1}$ of $\mathrm{N}, 80 \mathrm{~kg} \mathrm{ha}^{-1}$ of $\mathrm{P}_{2} \mathrm{O}_{5}, 120 \mathrm{~kg} \mathrm{ha}^{-1}$ of $\mathrm{K}_{2} \mathrm{O}$ ), and only then, after-stable yields were obtained, compared doses of 100 or $160 \mathrm{~kg} \mathrm{ha}^{-1}$ of $\mathrm{N}$ applied as sewage sludge ( 13 and $20 \mathrm{Mg} \mathrm{ha}^{-1}$, varying by year) versus mineral $\mathrm{N}$ at comparable rates and $50 \mathrm{~kg} \mathrm{ha}^{-1}$ of $\mathrm{P}_{2} \mathrm{O}_{5}$ and $100 \mathrm{~kg} \mathrm{ha}^{-1}$ of $\mathrm{K}_{2} \mathrm{O}$ applied to the mineral fertilizer treatments. Overall, yields varied only $20 \%$ over 6 years, between 17 and $22.5 \mathrm{tha}^{-1}$, presumably as a function of weather, with control plots consistently $20 \%$ lower than three treatments which did not differ from one another, and about $10 \%-15 \%$ lower than the lower level of 
applied sludge. This experiment indicated that for this soil, adding back $\mathrm{N}$ at the level that it is withdrawn by harvest is beneficial. Harvest was done relatively early in autumn, when only $1 / 3$ of leaves up the stem had dried, for use in silage for biogas production. Thus, the offtake of $\mathrm{N}$ was much greater than it would be in a late winter harvest. For instance, Kołodziej et al. (2016) saw a decrease of nearly two-fold in ash content of $M$. x giganteus when comparing autumn with spring harvested material. Iqbal et al. (2017) showed that offtake varies with harvest date at multiple locations with multiple CVs, consistent with the estimate that early harvest before nutrient translocation would remove 100-160 kg year-1 of $\mathrm{N}$, while later winter harvest would decrease this to $1 / 2$ or $1 / 3$ the amount. For combustion, lowered total mineral content is very important, whereas for biogas production it is not.

\subsection{Role of Soil Amendments}

Inorganic commercial fertilizers contain $\mathrm{N}, \mathrm{P}, \mathrm{K}$, as their main nutrients in the form of various salts, sometimes with $\mathrm{Ca}, \mathrm{Mg}, \mathrm{Zn}, \mathrm{S}, \mathrm{B}$, or trace elements added for specific soil types. These along with different organic fertilizers (compost, ash, manure, activated carbon) have historically been the primary soil amendments (Antonkiewicz et al., 2019; Boakye-Boaten et al., 2016; Lehmann et al., 2003). In the last 25 years different wastes like sewage sludge and digestate are becoming popular as soil amendments as well (Antonkiewicz et al., 2020; Kirchmann et al., 2017; Tabak et al., 2020). In addition, biochar, the solid material obtained from the carbonization of biomass/ waste or through pyrolysis, is currently proposed as both a soil amendment and carbon sequestration medium (Agegnehu et al., 2016; Faria et al., 2018; Lehmann et al., 2006). Application of soil amendments boosts the soil fertility balance and improves soil quality, resulting in increased crop yields (Hu et al., 2018; Humentik et al., 2018). Improvements in soil fertility result in greater uptake of macronutrients and micronutrients by plants, mainly in the second cropping season, and higher biomass productivity. Soil benefits include optimizing soil $\mathrm{pH}$, increasing moisture holding capacity, attracting more beneficial fungi and microbes, improving cation exchange capacity, and retaining nutrients. These benefits have been shown to increase yield in biomass and crops under variable conditions (Chan et al., 2008). One obvious energy cycle is to grow Miscanthus, pyrolyze it to recover energy, and use the residual biochar as a source of minerals and carbon for Miscanthus cultivation again.

The impacts of application of different soil amendments to the production of energy crops on regular agricultural soils are well represented in the literature. However, the improvements of biomass production when these crops are produced on marginal or contaminated soils are not researched 
so well. Only a few publications have evaluated changes in the phytoremediation parameters of the second-generation biomass crop Miscanthus when it is growing on contaminated soil receiving different soil amendments (Alasmary, 2020; Ameen et al., 2018; Kucharski et al., 2005; Mamirova et al., 2020). See Chapter 3 for some specific examples.

\subsubsection{Impact of Soil Amendments on the Phytoremediation of Soil Contaminated by Organic Substances}

Low molecular weight compounds. Plant roots secrete a wide range of chemical compounds: multicarboxylic organic acids including aconitic, citric, malic, malonic, oxalic, succinic, and tartaric acids; sugars and sugar conjugates; amino acids and peptides; phenolics, some of which are allelopathic; and diverse enzymes. Often the exudation results from complex interactions with the root microbiome (Korenblum et al., 2020). Exudation is sometimes initiated by lack of nutrients, pollutant toxicity, or anoxia (Dakora \& Phillips, 2002; Zeng et al., 2008). Root exudates thus serve to interact directly with contaminants, or indirectly by their influence on the microbiome. See Chapter 2 for more details.

In 1995, Hülster \& Marschner proposed a hypothesis that root exudates can bind with persistent organic pollutants in soil and form a more hydrophilic complex which can be more easily absorbed by roots and translocated to aboveground biomass. Campanella \& Paul (2000) supported this hypothesis, finding that Cucurbita pepo and melon (Cucumis melo) root exudates bind dioxins and furan molecules facilitating their translocation to aboveground biomass. They suggested that at least some part of this mix of carrier molecules was proteinaceous. The impact of organic acids, citrate, and EDTA (ethylenediaminetetraacetic acid) on the p, $\mathrm{p}^{\prime}$-DDE ( $\mathrm{p}, \mathrm{p}^{\prime}$-dichlorodiphenyl-1,1-dichloroethene) uptake by Cucurbita pepo, Trifolium incarnatum, Brassica juncea, Vicia villosa, and Lolium multiflorum was investigated by White et al. (2003) and White and Kottler (2002). They observed significant increases in uptake of p,p'-DDE for Cucurbita pepo (succinic acid - 19\%; tartaric acid $-27 \%$; malic acid $-31 \%$; malonic acid $-36 \%$; oxalic acid $-45 \%$; citric acid - 58\%; EDTA - 80\%) and for Trifolium incarnatum, Brassica juncea, and Vicia villosa (citrate $-39 \%$ ). Citrate also chelated metals, altering their bioavailability. More recently a $17 \mathrm{kDa}$ protein of the major latex protein class was identified in the xylem sap of $C$. pepo and shown by genetic means to be correlated with enhanced translocation of broad classes of POPs (Inui et al., 2013). So, it may be that there are multiple facilitators of their uptake at multiple steps.

Surface-active compounds. Surfactants are chemical compounds that decrease surface tension. Surfactants can reduce the hydrophobicity of organic compounds, for example, nonionic surfactants decreased the hydrophobicity of polychlorinated biphenyls in a soil-water system (Park \& Boyd, 1999). There are surfactants of chemical (Tweens, Polysorbate, Triton) and 
biological (e.g., rhamnolipids) origins. Gonzalez et al. (2010) reported that adding Tween 80 (nonionic) to contaminated soils effectively enhanced p,pDDT, p,p-DDE, and $\alpha$-cypermethrin solubility while adding sodium dodecyl sulfate (anionic) increased the solubility of two other pesticides ( $\alpha$-endosulfan and endosulfan sulfate).

Rhamnolipids, also called biosurfactants, are glycolipids produced by Pseudomonas, Burkholderia, and other genera (Abdel-Mawgoud et al., 2010). Amendment of soil contaminated with $\mathrm{p}, \mathrm{p}^{\prime}$-DDE by adding biosurfactants increased accumulation of pesticides in roots, leaves, and fruits of Cucurbita pepo ssp. Pepo (hyperaccumulator) and C. pepo ssp. Ovifera (nonaccumulator) mainly by reducing its net hydrophobicity (White et al., 2006).

Carbon-rich materials. Application of carbon-rich materials (biochar, activated carbon, lignite, etc.) in a phytoremediation process aims to stabilize organic pollutants by reducing their bioavailability (Denyes et al., 2012). A comparative study on potential of biochar and activated carbon to decrease the bioavailability of polychlorinated dibenzo- $p$-dioxins and -furans showed reduction of their bio-uptake in earthworms by 51.6\%-90.3\% (Chai et al., 2012). In the Chai et al. (2012) research, contaminant reduction was higher in soil treated by activated carbon whereas in Denyes et al. (2013) it was almost the same. The effectiveness of carbon-rich materials also depends on the way they were added to the system. In a mechanically mixed system ( 24 hours, $30 \mathrm{rpm}$ rotation in a drum) activated carbon reduced polychlorinated biphenyl levels 1.7 and 1.4 times more efficiently in the plant Cucurbita pepo and earthworm Eisenia fetida, respectively, while the effectiveness of biochar was higher by 2.0 and 1.7 times, respectively, as compared to simply digging the material into soil at a contaminated site (Denyes et al., 2013). Contact of contaminant and sorbent is slow in natural systems.

Nanoparticles. Nanoremediation is a relatively new area of environmental biotechnology, based on the ability of $\mathrm{Ag}, \mathrm{Au}, \mathrm{Mg}$, and Fe nanoparticles to facilitate dehalogenation of halocarbon pesticides. Nanoparticles can either directly react with contaminant or participate in its conversion into less toxic forms (Adeleye et al., 2013). Nanoparticles have been shown to be an efficient amendment able to degrade $100 \%$ of DDT in various matrices (Tian et al., 2009). Applying zero-valent iron nanoparticles (nZVIs) for DDT dechlorination in water and soil systems showed that the potential of nZVIs to decompose DDT was higher (92\%) in water than in soil (22.4\%) over the same time (El-Temsah et al., 2016). Unfortunately, different modes of preparation of the nZVI yield different eco-toxicity, which is nontrivial when it is applied in large amounts to obtain effective degradation of POPs such as DDT. The nZVIs were able to degrade lindane $(\gamma-\mathrm{HCH}$ (hexachlorohexane)) within 24 hours to $\gamma-3,4,5,6$-tetrachlorocyclohexane (an unstable intermediate) (Elliott et al., 2009). The high rates were largely driven by the very high surface area of nanoparticles, compared to larger ZVI particles.

Initial research combining nano- and phytotechnology to restore soil polluted by a chlorinated pesticide (endosulfan) included three tropical plant 
species: Alpinia calcarata, a large monocot in the ginger family; Ocimum sanctum, a perennial dicot type of basil; and Cymbopogon citratus, a true grass commonly called lemon grass, grown without or with nZVIs in pots (Pillai \& Kottekottil, 2016). These three species had been selected from 11 species grown at a level of $1 \mathrm{mg} \mathrm{kg}^{-1}$ endosulfan. The endosulfan concentration in soil for testing nZVI effects contained $1140 \mu \mathrm{g} \mathrm{kg}^{-1}$, while the optimized level of nZVI was $1 \mathrm{~g} \mathrm{~kg}^{-1}$. Ten $\mathrm{mL} \mathrm{kg}^{-1}$ of Tween 80 was used to disperse the nZVI; there were three replicates of six treatments. A. calcarata showed better phytoremediation potential in comparison to C. citratus and O. sanctum in both treatments: on the 7th day it removed $52 \%$ of endosulfan from pots without and $82 \%$ for pots with nZVIs; while on the 28th (last) day, endosulfan removal was $81 \%$ without and $100 \%$ with nZVIs at a level of $1 \mathrm{~g} \mathrm{~kg}^{-1}$. In the case of $O$. sanctum, addition of nZVIs to the system led to endosulfan removal increasing 3.7-fold over the plant alone ( $72 \%$ vs $21 \%$ ) on day 28 . With C. citratus, the main nZVI enhancement of endosulfan removal was observed after seven days ( $63 \%$ vs $5 \%)$. By day 14 the difference was $81 \%$ vs $60 \%$ and on day 28 with nZVIs removal was $86 \%$ and without nZVIs it was 65\% (Pillai \& Kottekottil, 2016). The patterns of rate difference are very nonlinear indicative of a perhaps second-order rate. Thus, the combined technology of nano- and phytoremediation is one of the promising areas for the remediation of organochlorine pesticides.

\subsubsection{Impact of Soil Amendments on Miscanthus Production in Postmilitary Soil}

The impact of soil amendments on Miscanthus biomass parameters was evaluated under field conditions with the crop cultivated in postmilitary soil, slightly contaminated by trace elements in Dolyna, Western Ukraine. Three different soil amendments were tested: lime GOST 14050-93; mineral fertilizer "Smolokot" (the nutrient content is N:P:K $=8: 8: 12,+7 \% \mathrm{MgO}+$ microelements); organic fertilizer "Agrolife" (N:P:K = 10:10:10 with chicken compost); and their mixture. Different fertilizers were mixed with the soil in a dose of $40 \mathrm{~g}$ per plant, while lime was $30 \mathrm{~g}$ per plant. The presoaked M. x giganteus rhizomes were planted directly into this mixture at a depth of $10 \mathrm{~cm}$. Results are presented in Figures 5.5-5.7. Treatment A1 is a control, with rhizomes soaked in water, planted without amendments to soil. A2-A5 all have rhizomes soaked in Charkor plant growth stimulant added $4 \mathrm{ml} \mathrm{L}^{-1}$ water. A2 has lime, A3 has AgroLife fertilizer, A4 has Smolokot fertilizer, and A5 has all three. All plots were $25 \mathrm{~m}^{2}$, with A1, A2, A5 receiving 56 propagules, with A3, and A4 having 42. There were three replicates of each treatment.

Through analysis of results from 3 years monitoring of $M$. x giganteus development in the contaminated military soil with application of different soil amendments, it may be concluded that the greatest effect was obtained when all three amendments were applied and the biggest influence was observed for dry mass production (Figure 5.7). The impact was small on crop height (Figure 5.6). 


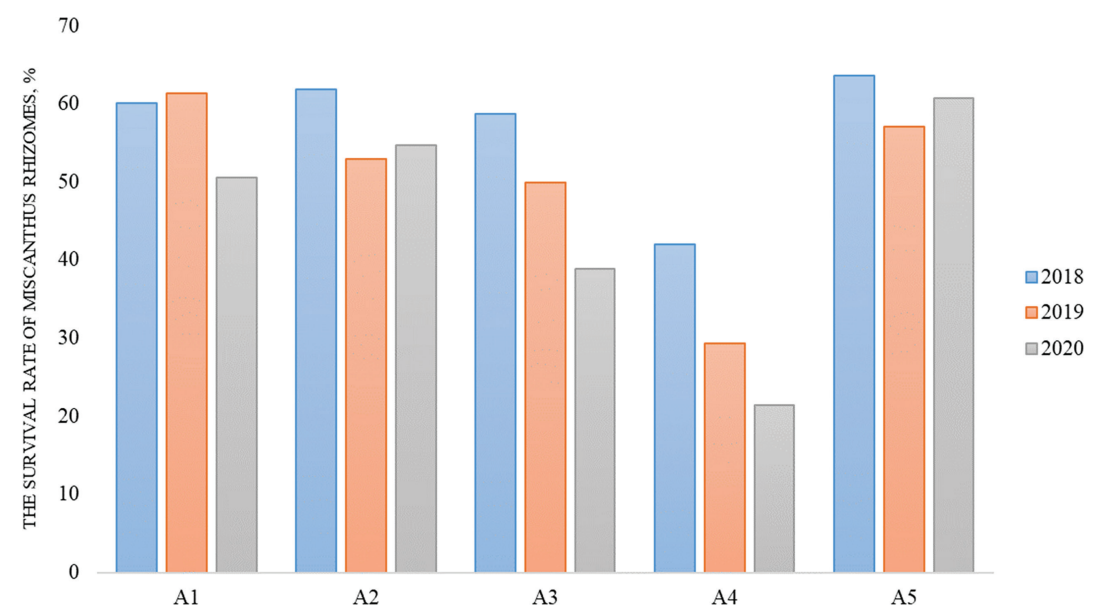

\section{FIGURE 5.5}

The mean winter survival rate of $M . x$ giganteus grown in the "postmilitary" soil with amendments, measured in spring of indicated year.

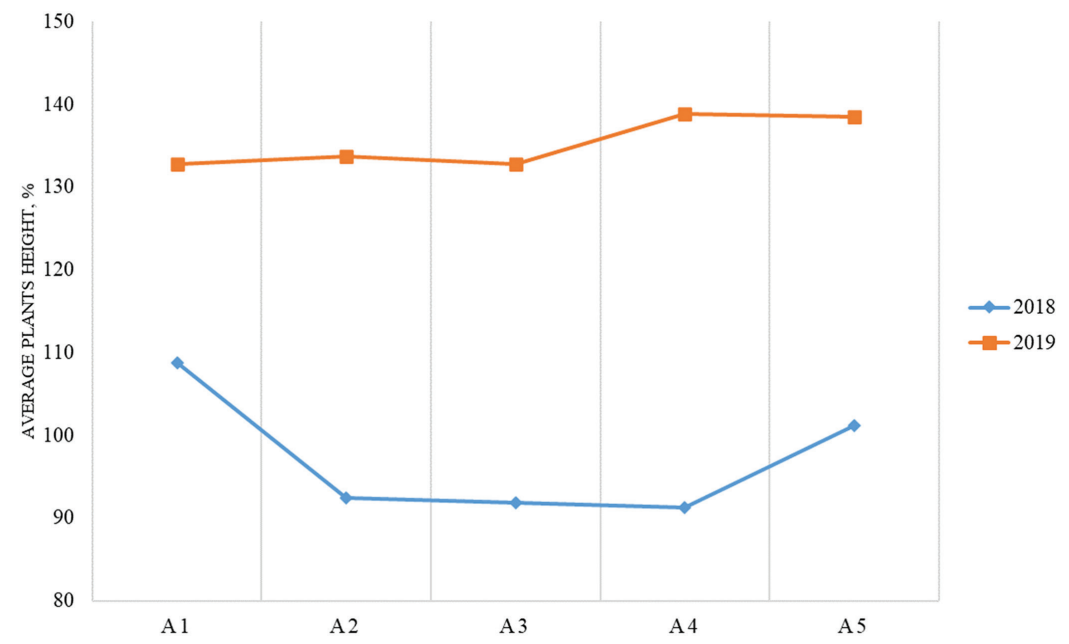

\section{FIGURE 5.6}

Plant heights of M. x giganteus when grown in "postmilitary" soil with amendments, measured in autumn of indicated year.

\subsubsection{Impact of Soil Amendments on Miscanthus Biomass Production in Contaminated Postmining Soil}

M. $x$ giganteus was tested for revitalization of postmining land with biomass production (Kharytonov et al., 2019). The research soil consisted of the mixture of loess-like loam and red-brown clay which had passed through a longterm phytomelioration stage. The soil humus content was about $1.5 \%$, and the 


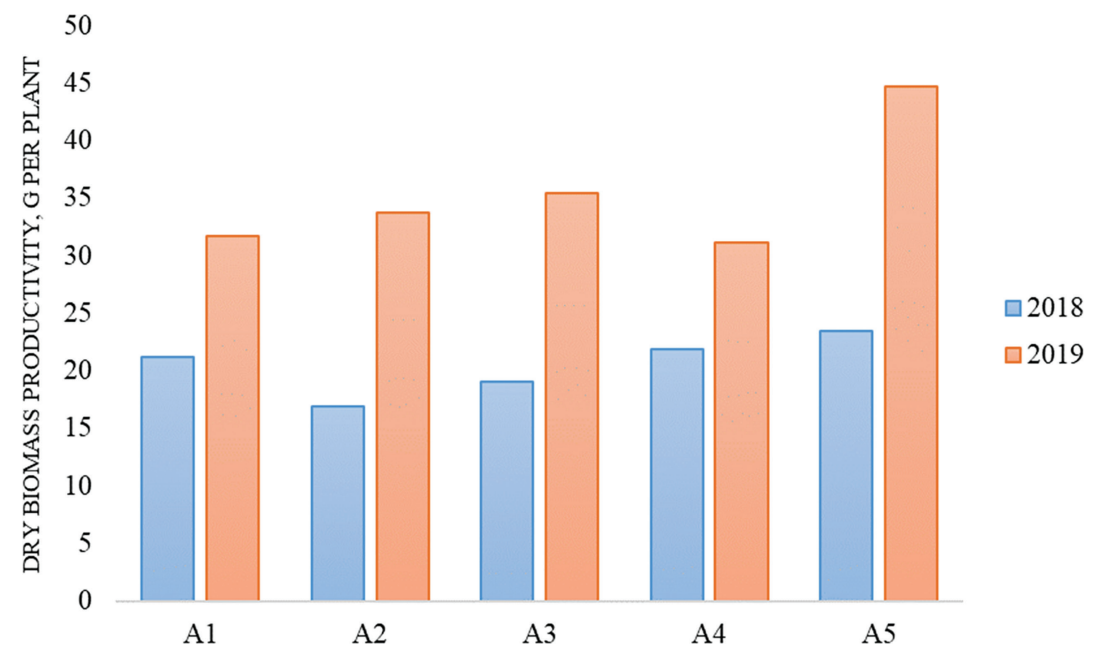

FIGURE 5.7

Mean dry biomass per surviving plant of $M$. xgiganteus for different amendments in the postmilitary soil.

ratio of humic and fulvic acids was $0.2-0.5$, which indicates a weak humus accumulation and active destruction of the soil mineral part. M. x giganteus showed sufficient tolerance and good enough growth and development in this postmining soil during 2 years of experimentation (Figure 5.8).

In order to determine the impact of amendments on the growth and development parameters of $M$. x giganteus, different amendments were applied: mineral fertilizer with a balance of nutrients $\mathrm{N}_{60}: \mathrm{P}_{60}: \mathrm{K}_{60} \mathrm{~kg} \mathrm{ha}^{-1}$; ash of sunflower hulls or sewage sludge each in the amount $10 \mathrm{tha}^{-1}$; a mixture of ash and sewage sludge (total $\left.10 \mathrm{tha}^{-1}\right)$; a double dose of sludge $\left(20 \mathrm{t} \mathrm{ha}^{-1}\right)$. The amendments were incorporated into soil in a dry form once before planting.

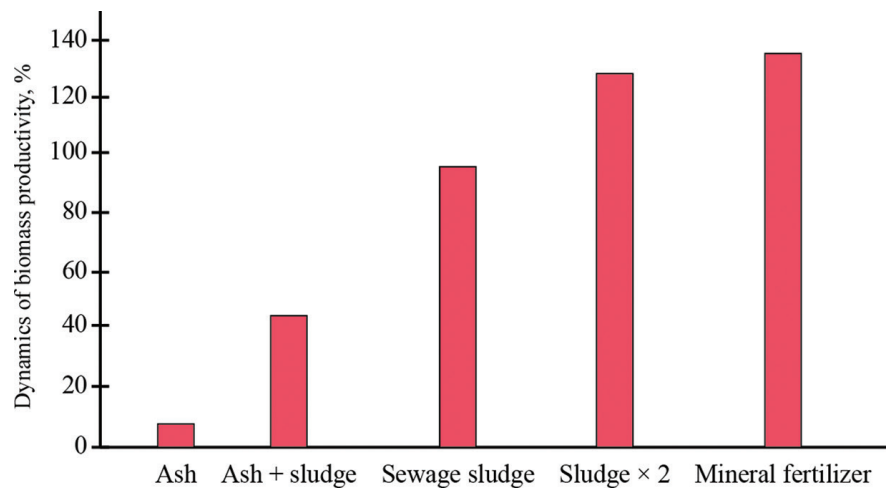

FIGURE 5.8

Miscanthus biomass productivity (\% increase over control plots) in the postmining soil with different amendments. (Modified from Kharytonov et al., 2019.) 
The results showed that the application of amendments positively affected the growth parameters of Miscanthus (Figures 5.8). The biggest effect was observed when plants grew in soil amended by mineral fertilizers, while the application of ash showed minimal increases of the growth parameters.

The increase of growth parameters promoted the enhancement of above ground biomass yield, and the degree of this enhancement was correlated with growth parameters, though for each the enhancement was different. In the case of ash application, yield increased by only $6.5 \%$ compared with the control, while the addition of mineral fertilizer or sewage sludge significantly increased the biomass yield by $2-2.3$ times. As a result, Miscanthus productivity in the second year was $11.6 \mathrm{t}$ dry matter $(\mathrm{DM}) \mathrm{ha}^{-1}$ with sludge and $11.9 \mathrm{t} \mathrm{DM} \mathrm{ha}^{-1}$ with mineral fertilizer. This research confirms earlier reported data (An et al., 2011; Kołodziej et al., 2016) that sewage sludge is conducive to increasing Miscanthus biomass yield.

The results illustrate that application of soil amendments can increase plant productivity by $50 \%-140 \%$ and that one can obtain Miscanthus yields similar to arable lands. Special attention should be paid to using sewage sludge as a promising substitute for organic fertilizers while growing $M$. x giganteus on postmining lands.

\subsection{Geography and Soil Types}

In the extensive review of Heaton et al. (2010) there is a very useful discussion of the impact of geology and soil type on M. x giganteus productivity. They cite several studies which indicate that an optimum soil is neither too sandy nor too dense, but intermediate in texture. This increases both water-holding capacity and aeration. Depth of soil is also important as water capacity depends on both texture and depth of soil. Capacity may be underestimated if a site is underlain by very porous rock which can effectively release water to the overlying soil during drought events or which can be reached by plant roots. Reasonable levels of clay improve capacity to store essential minerals including $\mathrm{K}, \mathrm{Ca}, \mathrm{Mg}$, and cationic trace elements. Lee et al. (2017) attributed the $\mathrm{N}$ response observed in their long-term study in part to the sandy nature of the soil being used and its relatively low retention of N. Organic matter increases the formation of aggregates and improves the overall tilth of the soil. In its native habitat of Japan, M. sinensis is able to pioneer and grow on volcanic ash-derived soils, and tolerates high levels of $\mathrm{Al}$ at low $\mathrm{pH}$ (Stewart et al., 2009). It contributes large amounts of organic matter to the developing soil in those conditions, where frequent fires over millennia have also contributed biochar.

As an example of successful production of Miscanthus on a potentially unfavorable site, we may consider the work of Skousen and co-workers in West Virginia (Scagline et al., 2015; Skousen et al., 2013). The site ( $38^{\circ} 49^{\prime} \mathrm{N}$, 
$80^{\circ} 11^{\prime} \mathrm{W}$ ) had been surface-mined, restored with mixed overburden, and $15 \mathrm{~cm}$ soil covering, fertilized, limed, and planted with mixed grass and legumes 25 years earlier. It had been managed as mown forbs during that time. Five replicate plots of 0.4 ha were planted to each of two types of M. $\times$ giganteus - public and private from Mendel Biotechnology (unnamed but likely Illinois and Nagara CVs). All plots were planted into a sod previously killed with glyphosate herbicide applied twice, fall and spring prior to planting. Planting density was 12,300 plugs ha ${ }^{-1}$. Even with a $>20 \%$ loss of plants this would still produce an appropriate plant density. Other plots received two types of switchgrass, drilled into the killed sod. Yields of switchgrass were 7.9 and $7.3 \mathrm{t} \mathrm{ha}^{-1}$ while the private $M$. $\times$ giganteus yielded 13.7 and the public $14.4 \mathrm{t} \mathrm{ha}^{-1}$ in year 5. The private CV increased yield much more rapidly over years than the public, reaching $22 \mathrm{t} \mathrm{ha}^{-1}$ in year 3 . However, all measures of Miscanthus had large variation (SD 50\%, N = 5 plots) likely because all yield measures were based on random selections of six plants, from large ( 0.4 ha) plots.

These $M . \times$ giganteus yields are very like those reported in the southcentral Virginia Piedmont region $\left(36^{\circ} 56^{\prime} \mathrm{N}, 79^{\circ} 24^{\prime} \mathrm{W}\right)$ in the same years by Lee et al. (2018) and Battaglia et al. (2019). Switchgrass yields in West Virginia (WV) were better than unfertilized soil of the Virginia (VA) portion of Lee et al. (2018) studies, but lower than on fertilized plots. For switchgrass, six $0.21 \mathrm{~m}^{2}$ quadrats were sampled on each of the WV switchgrass plots, but again the SD was very large. A critical methodological difference is that the studies of $M$. $\times$ giganteus coordinated by Lee et al. (2017) used a $4 \mathrm{~m}^{2}$ sample from the center of a plot of $10 \times 10 \mathrm{~m}$. With $\mathrm{N}=4$ for each different nitrogen fertilization level, the reported Standard Error of the Mean was much smaller, closer to $10 \%$. In the VA switchgrass study, there was a positive, usually large, response to added $\mathrm{N}$ each year. Their yields were measured by complete biomass harvest on full plots of at least 0.5 ha.

A very useful European example is the work of Jeżowski et al. (2017) who grew M. x giganteus on lignite mine spoils, with sewage sludge and mineral fertilizer supplements. Three years prior to planting Miscanthus, a mix of Medicago species was planted on the site which was roughly leveled. The wet sludge ( $1 \mathrm{Mg}$ per $5 \times 5 \mathrm{~m}$ treatment plot) was applied in the autumn prior to the Miscanthus planting and was incorporated into the soil to a depth of $\sim 30 \mathrm{~cm}$. This corresponds to $400 \mathrm{t} \mathrm{ha}^{-1}$ wet wt, $80 \mathrm{t}$ dry matter wt (DM). Rhizomes were planted on $1 \mathrm{~m}$ centers, 25 per plot, in a randomized, three complete blocks design. Treatments were $\mathrm{D}_{0}=$ no addition, $\mathrm{D}_{1}=$ addition of $\sim 80 \mathrm{Mg} \mathrm{ha}^{-1}(\mathrm{DM})$ of municipal sewage sludge, $\mathrm{D}_{2}=$ sludge $+200 \mathrm{~kg} \mathrm{ha}^{-1} \mathrm{com}-$ mercial fertilizer, $\mathrm{D}_{3}=$ sludge $+400 \mathrm{~kg} \mathrm{ha}^{-1}$ of commercial fertilizer. With a composition listed as 13:19:16 for N:P:K, the added fertilizer makes a modest $\mathrm{N}$ contribution of $\sim 26 \mathrm{~kg} \mathrm{ha}^{-1}$ to $\mathrm{D}_{2}$ and $\sim 52 \mathrm{~kg} \mathrm{ha}^{-1}$ to $\mathrm{D}_{3}$. Total $\mathrm{N}$ for the sludge was $43.4 \mathrm{~kg} \mathrm{Mg}^{-1} \mathrm{DM}$ (4.3\%) for an applied rate of over $3400 \mathrm{~kg} \mathrm{ha}^{-1}$, although most would be organic $\mathrm{N}$. If this mineralizes at a rate of $2 \%$ per year it contributes all the $\mathrm{N}$ needed by the amount of biomass produced, over a long time. 
Biomass yields increased year by year, but $D_{1}-D_{3}$ did not differ significantly from one another in any year. Within treatments yield estimates varied $\pm 20 \%$. "From the center of each plot, six randomly selected plants were collected". Yields in year 3 were $\sim 9 \mathrm{Mg} \mathrm{ha}^{-1}$ for the control $\mathrm{D}_{0}$ and $\sim 15$ $\mathrm{Mg} \mathrm{ha}^{-1}$ for the three treatments with sludge. This represents a positive use for a marginal land. The authors estimated that it might take 7-10 years to become profitable as a crop, because of establishment and harvest costs.

Overall, there is good evidence that geographic location is very important to potential M. x giganteus yields, as reviewed by Heaton et al. (2010), independent of fertility of soil, addition of fertilizers, and other nutrient amendments. Latitude influences time of flowering and yield. Higher latitudes delay flowering. Rainfall patterns (timing and amounts) and temperature regimes determine the regions where rain-fed crops can be successfully grown for maximum production. Continental vs oceanic climates markedly affect stability of yields. For the U.S. there are adaptability maps showing likely zones of relative yield, based on models of $M$. x giganteus growth patterns. There have been enough regional studies to indicate that in some locations alternatives other than M. xgiganteus are more productive at least for a few years of study (Smith et al., 2015b). There have not been sufficient long-term studies to say how they would fare over the course of decades. Similar maps have also been developed with alternate bioenergy crops including maize, switchgrass, sorghum, and select sugarcane CVs identified as "Energy Cane" (Matsuoka et al., 2014). For total biomass production in the south of US, M. x giganteus cannot compete with Energy Cane.

Very sophisticated models of growth patterns for M. x giganteus in Europe have been developed. Early examples are discussed in Heaton et al. (2010). These have good predictive values when key features including latitude, hours of light, water, and temperature are input to the models.

\subsection{Role of Plant Growth Regulators in Production of $M . \times$ giganteus}

Plant growth regulators (PGRs, earlier term "phytohormones") are a group of treatment substances used for enhancing plant growth (Procházka \& Šebánek, 1997). There are five main classical groups of natural PGRs: auxins, cytokinins, gibberellins, ethylene, abscisic acid; in addition, there is a class of "new plant hormones" formed by brassinosteroids, salicylic acid, jasmonates, and strigolactones. For each class there are substances chemically or biologically synthesized and used as mimics or inhibitors (agonists and antagonists in biochemical terminology). Also, oligosaccharides, systemin, polyamines, reactive oxygen species, and reactive nitrogen species including nitric oxide possess activities similar to those of plant hormones in various 
systems (Bhattacharyya \& Jha, 2012; Chen et al., 2009; George et al., 2008; Ponomarenko et al., 2010, 2017).

Applications of PGRs have been studied in Europe for increasing the production of different agricultural crops: wheat, maize, sunflowers (Ponomarenko et al., 2010; Tsygankova et al., 2013a). A total of 14 different PGRs produced by Agrobiotech Company (Ukraine), based on natural active ingredients, were tested on Sorghum bicolor L., sunflowers, wheat, and maize production, and the best results were received for two PGRs, Stimpo and Regoplant. While growing sunflowers, treatment with these PGRs increased the plant weight by $6.4 \%$ and the number of seeds in a head by $13.0 \%$. In the case of maize production such treatment increased plant height by $11.5 \%$, leaf surface area by $12.7 \%$, and root length by $12.5 \%$.

The application of PGRs to plants that grow on contaminated land may protect the photosynthetic apparatus from oxidative shock induced by contaminants, increase root length, increase shoot growth, enhance the transpiration rate and yield (Israr et al., 2011; Liphadzi et al., 2006). The use of PGRs usually results in benefit with little risk of negative environmental effects, and PGRs may also boost plant immunity to pests and pathogens (Ponomarenko et al., 2013; Tsygankova et al., 2013b). Only a few publications exist on the impact of PGRs in $M$. x giganteus production, when a crop was grown on regular agricultural soil during one vegetation season (Zinchenko, 2013). Treatment of $M$. x giganteus before planting with three PGRs Regoplant, Emistin, and Agrostimylin produced by AgroBiotech Company (Ukraine) increased the activity of photosynthesis and improved the survival rate. The treatment by PGRs stimulated plant development by increasing the number of stems and the overall crop height. The application of the same PGRs, Regoplant, Emistin, and Agrostimylin, increased the photosynthesis rate when $M$. x giganteus was cultivated in the soil contaminated by radionuclides and gave an increase in the biomass at harvest of about 18.8\%-25.3\% (Zinchenko et al., 2016; Zinchenko et al., 2009).

\subsubsection{Lab Research on Impact of PGRs on Phytoremediation with Biomass Production Using Soils from Military Sites Contaminated with Trace Elements}

The impact of two PGRs, Stimpo and Regoplant, was tested in pots, with four soils taken from two military sites of different origins (Dolyna, Ukraine and Mimon, Czech Republic, two from each area). Soils in both cases were slightly contaminated by heavy metals (Nebeská et al., 2019). PGRs were produced by AgroBiotech Company (Ukraine) and consisted of a balanced composition of biologically active compounds, namely, analogues of phytohormones, amino acids, fatty acids, oligosaccharides, microelements, and bioprotective compounds. The treatment of rhizomes was done before planting and by spraying on the biomass during growth. The results obtained (Nebeská et al., 2019) showed that the main factor driving the increase of biomass parameters was the agricultural characteristics of the soil: the better it was the greater 
the effect of PGRs treatment was (case of Dolyna soil). Conversely, the effect was almost negligible in soils poor in nutrients and organic matter (case of Mimon soil). Between the two tested PGRs the effect of Regoplant was more obvious. The best results were obtained with combined treatment of application to rhizomes before planting and spraying of biomass during the vegetation season (Nebeská et al., 2019).

The impact of PGR treatment on phytoremediation parameters was evaluated as well. When M. x giganteus was growing in soil richer in nutrients the process of metals uptake was in accordance with the general trend for Miscanthus (Pidlisnyuk et al., 2014) and recognized as phytostabilization. That is, the majority of the metals accumulated in the roots. The bioaccumulation behavior of the monitored metals was different when a crop was grown in sandy soil with poor nutrient content. While the nonessential elements $\mathrm{Cr}$ and $\mathrm{Pb}$ were as expected dominantly accumulated in roots, $\mathrm{Ni}$ was not detected and biogenic elements ( $\mathrm{Mn}, \mathrm{Cu}, \mathrm{Zn}$ ) were more intensively taken up into shoots in comparison with roots. This was attributed to stress caused by deficient soil characteristics (Kabata-Pendias \& Pendias, 2001; Nebeská et al., 2019).

\subsubsection{Field Research on Impact of PGRs on Biomass Parameters of $M$. × giganteus during Field Production on the Marginal and Slightly Contaminated Lands}

Two PGRs, Stimpo and Charkor, were evaluated in the field conditions and tested for production of Miscanthus on marginal agricultural land in the Central Ukraine (Pidlisnyuk \& Stefanovska, 2018). The dose for the treatment was the same as in the Lab experiment (Nebeská et al., 2019). The results received after first year of plant's growth showed about $20 \%$ increase of biomass when rhizomes were treated by Stimpo, and about $28 \%$ increase when rhizomes were treated by Charkor (Table 5.1).

\section{TABLE 5.1}

Bioparameters of M. $\times$ giganteus When a Crop Was Produced on the Marginal Agricultural Land with Treatment of Rhizomes by PGRs

\begin{tabular}{lllcc}
\hline \multirow{2}{*}{ Treatment } & \multicolumn{2}{l}{$\begin{array}{l}\text { Structure of } \\
\text { Harvest (\%) }\end{array}$} & Harvest, Dry Biomass/Plant (g) & Increase (\%) \\
\hline Water (control) & Leaves & 21.0 & 6.5 & - \\
& Stems & 79.0 & & 20 \\
Stimpo plantation & Leaves & 21.0 & 7.8 & 28 \\
& Stems & 79.0 & & \\
Charkor 1 plantation & Leaves & 26.0 & 8.3 & 28 \\
& Stems & 74.0 & & \\
\multirow{2}{*}{ Charkor 2 plantation } & Leaves & 26.0 & 8.3 & \\
& Stems & 74.0 & &
\end{tabular}

Source: Modified from Pidlisnyuk and Stefanovska (2018). 
In another experiment in Dolyna, Western Ukraine, the PGR Charkor showed the best results in comparison with Stimpo and Regoplant during multiple years of $M$. x giganteus production on the military soil slightly contaminated with trace elements (Figures 5.9-5.11). Application of Charkor improved the overwinter survival rate, average plant height at harvest, and dry biomass productivity in comparison with control treatment by water or two other tested PGRs: Stimpo and Regoplant.

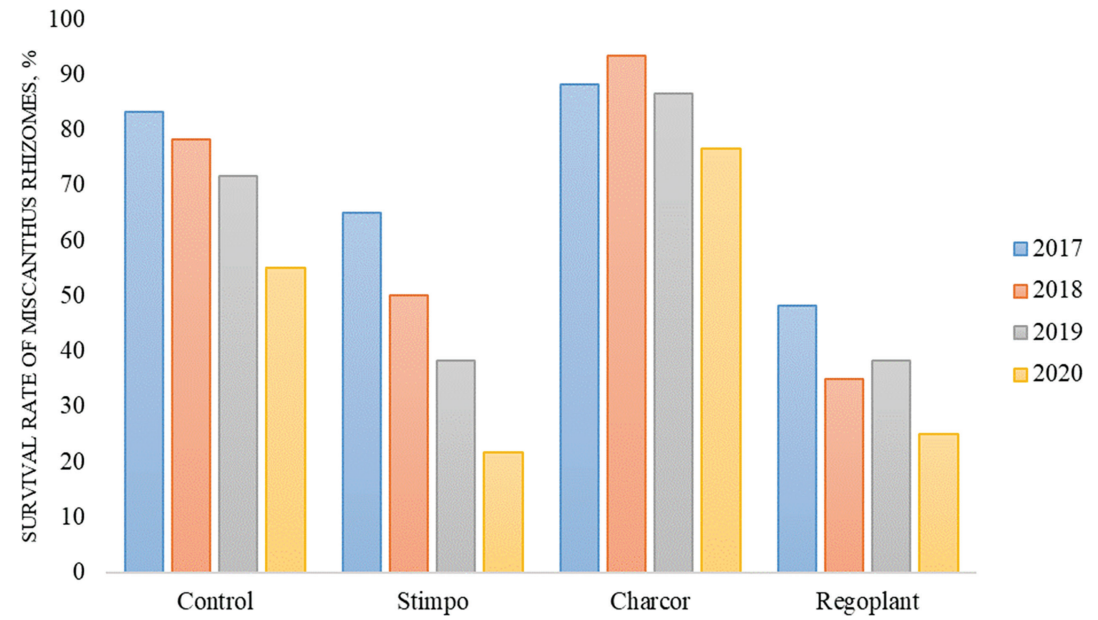

FIGURE 5.9

Winter survival rate of M. x giganteus plants, until spring of the indicated year.

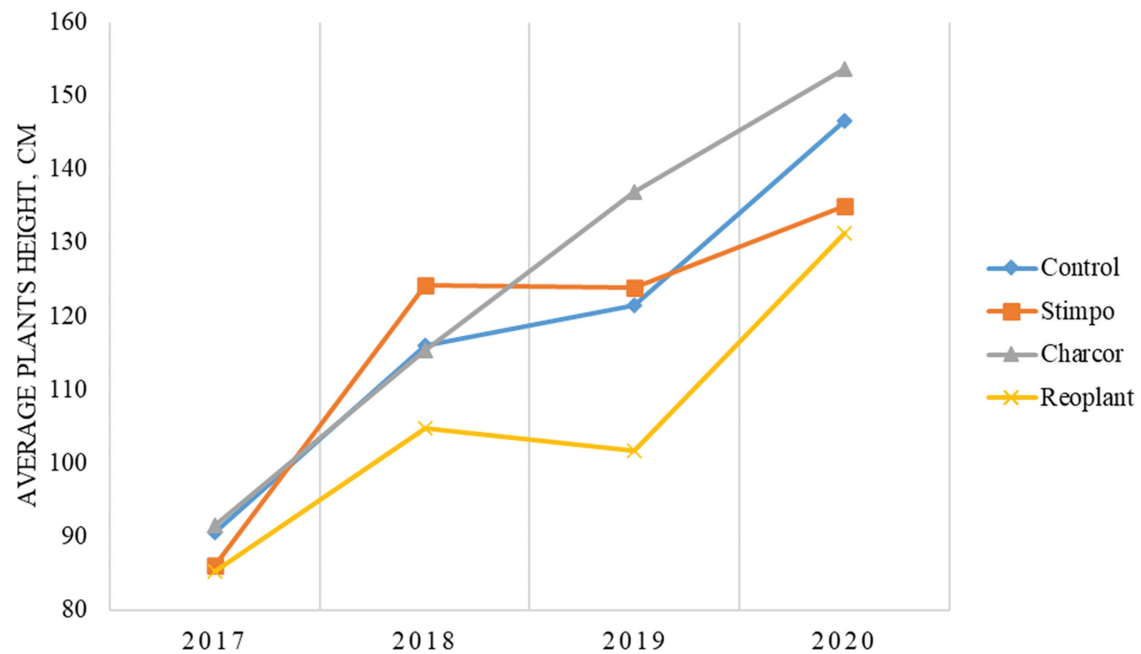

FIGURE 5.10

Average plant height of $M$. x giganteus at harvest, $\mathrm{cm}$. 


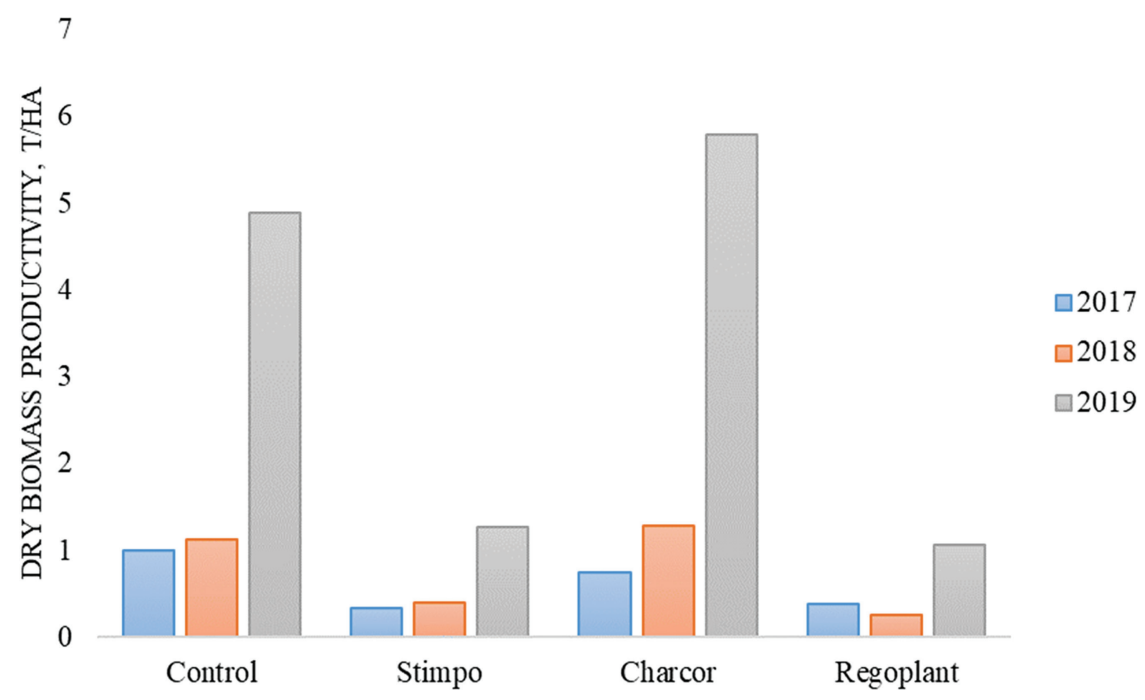

FIGURE 5.11

Dry biomass productivity of $\mathrm{M} . \times$ giganteus, $\mathrm{Mg} \mathrm{ha}^{-1}$.

PGRs can be recommended as substances which improve the biomass parameters of $M$. $x$ giganteus when the crop is growing on marginal or slightly contaminated soils of military origin. The best results were received for Charkor which showed the biggest increase of biomass along with improvement of the survival rate compared to other tested PGRs, Stimpo and Regoplant. When PGRs were applied to soil depleted of nutrients the effect of these substances was very little.

\section{References}

Abdel-Mawgoud, A. M., Lépine, F., \& Déziel, E. (2010). Rhamnolipids: Diversity of structures, microbial origins and roles. Applied Microbiology and Biotechnology, 86(5), 1323-1336. https://doi.org/10.1007/s00253-010-2498-2.

Adeleye, A. S., Keller, A. A., Miller, R. J., \& Lenihan, H. S. (2013). Persistence of commercial nanoscaled zero-valent iron (nZVI) and by-products. Journal of Nanoparticle Research, 15(1), 1418. https://doi.org/10.1007/s11051-013-1418-7.

Agegnehu, G., Bass, A. M., Nelson, P. N., \& Bird, M. I. (2016). Benefits of biochar, compost and biochar-compost for soil quality, maize yield and greenhouse gas emissions in a tropical agricultural soil. Science of the Total Environment, 543, 295-306. https://doi.org/10.1016/j.scitotenv.2015.11.054.

Alasmary, Z. (2020). Laboratory- to field-scale investigations to evaluate phosphate amendments and Miscanthus for phytostabilization of lead-contaminated military sites [PhD Dissertation, Kansas State University]. https://krex.k-state.edu/dspace/ handle/2097/40676. 
Ameen, A., Tang, C., Han, L., \& Xie, G. H. (2018). Short-term response of switchgrass to nitrogen, phosphorus, and potassium on semiarid sandy wasteland managed for biofuel feedstock. BioEnergy Research, 11(1), 228-238. https://doi. org/10.1007/s12155-018-9894-3.

An, G. H., Lee, S., Koo, B. C., Choi, Y. H., Moon, Y. H., Cha, Y. L., Bark, S. T., Kim, J. K., Kim, B. C., \& Kim, S. P. (2011). Effects of application of solidified sewage sludge on the growth of bioenergy crops in reclaimed land. Korean Journal of Crop Science/Hanguk Jakmul Hakhoe Chi, 56(4), 299-307. https://doi.org/10.7740/kjcs. 2011.56.4.299.

Anderson, E. K. (2010). Herbicide phytotoxicity response and eradication studies on Miscanthus $\times$ giganteus [MS Thesis, University of Illinois]. http://hdl.handle. net/2142/18498.

Anderson, E. K., Arundale, R., Maughan, M., Oladeinde, A., Wycislo, A., \& Voigt, T. (2011). Growth and agronomy of Miscanthus $\times$ giganteus for biomass production. Biofuels, 2(1), 71-87. https://doi.org/10.4155/bfs.10.80.

Anderson, E. K., Lee, D., Allen, D. J., \& Voigt, T. B. (2015). Agronomic factors in the establishment of tetraploid seeded Miscanthus x giganteus. GCB Bioenergy, 7(5), 1075-1083. https://doi.org/10.1111/gcbb.12192.

Antonkiewicz, J., Kołodziej, B., Bielińska, E. J., \& Popławska, A. (2019). The possibility of using sewage sludge for energy crop cultivation exemplified by reed canary grass and giant miscanthus. Soil Science Annual, 70(1), 21-33. https://doi. org/10.2478/ssa-2019-0003.

Antonkiewicz, J., Popławska, A., Kołodziej, B., Ciarkowska, K., Gambuś, F., Bryk, M., \& Babula, J. (2020). Application of ash and municipal sewage sludge as macronutrient sources in sustainable plant biomass production. Journal of Environmental Management, 264, 110450. https://doi.org/10.1016/j.jenvman.2020.110450.

Aurangzaib, M. (2012). Performance evaluation of nine varieties of Miscanthus in Iowa [Master Thesis, Iowa State University]. https://lib.dr.iastate.edu/etd/12690.

Awty-Carroll, D., Hauck, B., Clifton-Brown, J., \& Robson, P. (2020). Allelopathic and intraspecific growth competition effects on establishment of direct sown Miscanthus. GCB Bioenergy, 12(6), 396-409. https://doi.org/10.1111/gcbb.12680.

Battaglia, M., Fike, J., Fike, W., Sadeghpour, A., \& Diatta, A. (2019). Miscanthus x giganteus biomass yield and quality in the Virginia Piedmont. Grassland Science, 65(4), 233-240. https://doi.org/10.1111/grs.12237.

Bhattacharyya, P. N., \& Jha, D. K. (2012). Plant growth-promoting rhizobacteria (PGPR): Emergence in agriculture. World Journal of Microbiology and Biotechnology, 28(4), 1327-1350. https://doi.org/10.1007/s11274-011-0979-9.

Boakye-Boaten, N. A., Xiu, S., Shahbazi, A., Wang, L., Li, R., Mims, M., \& Schimmel, K. (2016). Effects of fertilizer application and dry/wet processing of Miscanthus $\times$ giganteus on bioethanol production. Bioresource Technology, 204, 98-105. https://doi.org/10.1016/j.biortech.2015.12.070.

Boersma, N. N., Dohleman, F. G., Miguez, F. E., \& Heaton, E. A. (2015). Autumnal leaf senescence in Miscanthus $\times$ giganteus and leaf [N] differ by stand age. Journal of Experimental Botany, 66(14), 4395-4401. https://doi.org/10.1093/jxb/ery129.

Boersma, N. N., \& Heaton, E. A. (2012). Effects of temperature, illumination and node position on stem propagation of Miscanthus $\times$ giganteus. GCB Bioenergy, 4(6), 680-687. https://doi.org/10.1111/j.1757-1707.2011.01148.x.

Boersma, N. N., \& Heaton, E. A. (2014a). Does propagation method affect yield and survival? The potential of Miscanthus $\times$ giganteus in Iowa, USA. Industrial Crops and Products, 57, 43-51. https://doi.org/10.1016/j.indcrop.2014.01.058. 
Boersma, N. N., \& Heaton, E. A. (2014b). Propagation method affects Miscanthus $\times$ giganteus developmental morphology. Industrial Crops and Products, 57, 59-68. https://doi.org/10.1016/j.indcrop.2014.01.059.

Campanella, B., \& Paul, R. (2000). Presence, in the Rhizosphere and leaf extracts of Zucchini (Cucurbita pepo L.) and melon (Cucumis melo L.), of molecules capable of increasing the apparent aqueous solubility of hydrophobic pollutants. International Journal of Phytoremediation, 2(2), 145-158. https://doi. org/10.1080/15226510008500036.

Caslin, B., Finnan, J., \& Easson, L. (2011). Miscanthus best practices guidelines. http:// greenbiomassenergy.com/wp-content/uploads/2020/02/Miscanthus Best Practice Manual 190913.pdf.

Chai, Y., Currie, R. J., Davis, J. W., Wilken, M., Martin, G. D., Fishman, V. N., \& Ghosh, U. (2012). Effectiveness of activated carbon and biochar in reducing the availability of polychlorinated dibenzo-p-dioxins/dibenzofurans in soils. Environmental Science E Technology, 46(2), 1035-1043. https://doi.org/10.1021/es2029697.

Chan, K. Y., Zwieten, L. V., Meszaros, I., Downie, A., \& Joseph, S. (2008). Agronomic values of greenwaste biochar as a soil amendment. Soil Research, 45(8), 629-634. https://doi.org/10.1071/SR07109.

Chen, C., Zou, J., Zhang, S., Zaitlin, D., \& Zhu, L. (2009). Strigolactones are a newdefined class of plant hormones which inhibit shoot branching and mediate the interaction of plant-AM fungi and plant-parasitic weeds. Science in China Series C: Life Sciences, 52(8), 693-700. https://doi.org/10.1007/s11427-009-0104-6.

Clifton-Brown, J. C., Hastings, A., Mos, M., et al. (2017). Progress in upscaling Miscanthus biomass production for the European bio-economy with seedbased hybrids. GCB Bioenergy, 9(1), 6-17. https://doi.org/10.1111/gcbb.12357.

Clifton-Brown, J. C., \& Lewandowski, I. (2000). Water use efficiency and biomass partitioning of three different Miscanthus genotypes with limited and unlimited water supply. Annals of Botany, 86(1), 191-200. https://doi.org/10.1006/ anbo.2000.1183.

Clifton-Brown, J. C., Schwarz, K.-U., Awty-Carroll, D., et al. (2019). Breeding strategies to improve Miscanthus as a sustainable source of biomass for bioenergy and biorenewable products. Agronomy, 9(11), 673. https://doi.org/10.3390/ agronomy 9110673.

Cosentino, S. L., Patanè, C., Sanzone, E., Copani, V., \& Foti, S. (2007). Effects of soil water content and nitrogen supply on the productivity of Miscanthus $\times$ giganteus Greef et Deu. in a Mediterranean environment. Industrial Crops and Products, 25(1), 75-88. https://doi.org/10.1016/j.indcrop.2006.07.006.

Dakora, F. D., \& Phillips, D. A. (2002). Root exudates as mediators of mineral acquisition in low-nutrient environments. In J. J. Adu-Gyamfi (Ed.), Food Security in Nutrient-Stressed Environments: Exploiting Plants' Genetic Capabilities (pp. 201213). Springer, Netherlands. https://doi.org/10.1007/978-94-017-1570-6_23.

Davis, S. C., Parton, W. J., Dohleman, F. G., Smith, C. M., Grosso, S. D., Kent, A. D., \& DeLucia, E. H. (2010). Comparative biogeochemical cycles of bioenergy crops reveal nitrogen-fixation and low greenhouse gas emissions in a Miscanthus $\times$ giganteus agro-ecosystem. Ecosystems, 13(1), 144-156. https://doi. org/10.1007/s10021-009-9306-9.

Denyes, M. J., Langlois, V. S., Rutter, A., \& Zeeb, B. A. (2012). The use of biochar to reduce soil PCB bioavailability to Cucurbita pepo and Eisenia foetida. Science of the Total Environment, 437, 76-82. https://doi.org/10.1016/j.scitotenv.2012.07.081. 
Denyes, M. J., Rutter, A., \& Zeeb, B. A. (2013). In situ application of activated carbon and biochar to PCB-contaminated soil and the effects of mixing regime. Environmental Pollution,182,201-208.https://doi.org/10.1016/j.envpol.2013.07.016.

Dong, H., Green, S. V., Nishiwaki, A., Yamada, T., Stewart, J. R., Deuter, M., \& Sacks, E. J. (2019). Winter hardiness of Miscanthus (I): Overwintering ability and yield of new Miscanthus x giganteus genotypes in Illinois and Arkansas. GCB Bioenergy, 11(5), 691-705. https://doi.org/10.1111/gcbb.12588.

Doronin, V. A., Dryha, V. V., Kravchenko, Y. A., Mykolaiko, V. P., Karpuk, L. M., \& Krasnoshtan, I. V. (2019). Growing of Miscanthus x giganteus planting material in the conditions of unstable moistening. Eurasian Journal of Biosciences, 13(2), 1101-1108. http://www.ejobios.org/article/growing-of-miscantus-giganteusplanting-material-in-the-conditions-of-unstable-moistening-7231.

Dubis, B., Jankowski, K. J., Załuski, D., \& Sokólski, M. (2020). The effect of sewage sludge fertilization on the biomass yield of giant miscanthus and the energy balance of the production process. Energy, 206, 118189. https://doi.org/10.1016/j. energy.2020.118189.

Elliott, D. W., Lien, H.-L., \& Zhang, W.-X. (2009). Degradation of lindane by zerovalent iron nanoparticles. Journal of Environmental Engineering, 135(5), 317-324. https://doi.org/10.1061/(asce)0733-9372(2009)135:5(317).

El-Temsah, Y. S., Sevcu, A., Bobcikova, K., Cernik, M., \& Joner, E. J. (2016). DDT degradation efficiency and ecotoxicological effects of two types of nano-sized zerovalent iron (nZVI) in water and soil. Chemosphere, 144, 2221-2228. https://doi. org/10.1016/j.chemosphere.2015.10.122.

Evanylo, G. K. (2006). Chapter 10. Land application of biosolids. In K. C. Haering \& G. K. Evanylo (Eds.), The Mid-Atlantic Nutrient Management Handbook (p.27). Virginia Cooperative Extension, Blacksburg, VA. https://vtechworks.lib.vt.edu/ handle/10919/99502.

Faria, W. M., de Figueiredo, C. C., Coser, T. R., Vale, A. T., \& Schneider, B. G. (2018). Is sewage sludge biochar capable of replacing inorganic fertilizers for corn production? Evidence from a two-year field experiment. Archives of Agronomy and Soil Science, 64(4), 505-519. https://doi.org/10.1080/03650340.2017.1360488.

George, E. F., Hall, M. A., \& Klerk, G.-J. D. (2008). Plant growth regulators I: Introduction; Auxins, their analogues and inhibitors. In E. F. George, M. A. Hall, \& G.-J. D. Klerk (Eds.), Plant Propagation by Tissue Culture (3rd ed., Vol. 1, pp.175-204).Springer,Netherlands.https://doi.org/10.1007/978-1-4020-5005-3_5.

Gonzalez, M., Miglioranza, K. S. B., Aizpún, J. E., Isla, F. I., \& Peña, A. (2010). Assessing pesticide leaching and desorption in soils with different agricultural activities from Argentina (Pampa and Patagonia). Chemosphere, 81(3), 351-358. https://doi. org/10.1016/j.chemosphere.2010.07.021.

Heaton, E. A., Dohleman, F. G., Miguez, A. F., Juvik, J. A., Lozovaya, V., Widholm, J., Zabotina, O. A., McIsaac, G. F., David, M. B., Voigt, T. B., Boersma, N. N., \& Long, S. P. (2010). Chapter 3: Miscanthus: A promising biomass crop. In J.-C. Kader \& M. Delseny (Eds.), Advances in Botanical Research (Vol. 56, pp. 75-137). Academic Press, London, UK. https://doi.org/10.1016/B978-0-12-381518-7.00003-0.

Hu, B., Jarosch, A.-M., Gauder, M., Graeff-Hönninger, S., Schnitzler, J.-P., Grote, R., Rennenberg, H., \& Kreuzwieser, J. (2018). VOC emissions and carbon balance of two bioenergy plantations in response to nitrogen fertilization: A comparison of Miscanthus and Salix. Environmental Pollution, 237, 205-217. https://doi. org/10.1016/j.envpol.2018.02.034. 
Hülster, A., \& Marschner, H. (1995). PCDD/PCDF-complexing compounds in zucchini. Organohalogen Compounds, 24, 493-496.

Humentik, M., Radejko, B., Fuchilo, Ya., Sinchenko, V., Ganzhenko, O., Bondar, V., Fursa, A., Kvak, V., Kharitonov, M., \& Katelevskyi, V. (2018). Production of Bioenergy Crops (M. Humentik, Ed.). Komprint.

Inui, H., Sawada, M., Goto, J., Yamazaki, K., Kodama, N., Tsuruta, H., \& Eun, H. (2013). A major latex-like protein is a key factor in crop contamination by persistent organic pollutants. Plant Physiology, 161(4), 2128-2135. https://doi.org/10.1104/ pp.112.213645.

Iqbal, Y., Kiesel, A., Wagner, M., Nunn, C., Kalinina, O., Hastings, A. F. S. J., CliftonBrown, J. C., \& Lewandowski, I. (2017). Harvest time optimization for combustion quality of different Miscanthus genotypes across Europe. Frontiers in Plant Science, 8, 727. https://doi.org/10.3389/fpls.2017.00727.

Israr, M., Jewell, A., Kumar, D., \& Sahi, S. V. (2011). Interactive effects of lead, copper, nickel and zinc on growth, metal uptake and antioxidative metabolism of Sesbania drummondii. Journal of Hazardous Materials, 186(2), 1520-1526. https:// doi.org/10.1016/j.jhazmat.2010.12.021.

Jeżowski, S., Mos, M., Buckby, S., Cerazy-Waliszewska, J., Owczarzak, W., Mocek, A., Kaczmarek, Z., \& McCalmont, J. P. (2017). Establishment, growth, and yield potential of the perennial grass Miscanthus $\times$ giganteus on degraded coal mine soils. Frontiers in Plant Science, 8, 726. https://doi.org/10.3389/fpls.2017.00726.

Kabata-Pendias, A., \& Pendias, H. (2001). Trace Elements in Soils and Plants (3rd ed.). CRC Press, Boca Raton, FL.

Kaiser, C. M., \& Sacks, E. J. (2015). Cold-tolerance of Miscanthus seedlings and effects of spring and autumn frosts on mature clonally replicated cultivars. Crop Science, 55(5), 2401-2416. https://doi.org/10.2135/cropsci2014.10.0679.

Kalinina, O., Nunn, C., Sanderson, R., Hastings, A. F. S., van der Weijde, T., Özgüven, M., Tarakanov, I., Schüle, H., Trindade, L. M., Dolstra, O., Schwarz, K.-U., Iqbal, Y., Kiesel, A., Mos, M., Lewandowski, I., \& Clifton-Brown, J. C. (2017). Extending Miscanthus cultivation with novel germplasm at six contrasting sites. Frontiers in Plant Science, 8, 563. https://doi.org/10.3389/fpls.2017.00563.

Kansas Corn Yield Contest Winners. (2019). https://kscorn.com/yield-2/.

Kering, M. K., Butler, T. J., Biermacher, J. T., \& Guretzky, J. A. (2012). Biomass yield and nutrient removal rates of perennial grasses under nitrogen fertilization. BioEnergy Research, 5(1), 61-70. https://doi.org/10.1007/s12155-011-9167-x.

Kharytonov, M., Pidlisnyuk, V., Stefanovska, T., Babenko, M., Martynova, N., \& Rula, I. (2019). The estimation of Miscanthus $\times$ giganteus' adaptive potential for cultivation on the mining and post-mining lands in Ukraine. Environmental Science and Pollution Research, 26(3), 2974-2986.

Kirchmann, H., Börjesson, G., Kätterer, T., \& Cohen, Y. (2017). From agricultural use of sewage sludge to nutrient extraction: A soil science outlook. Ambio, 46(2), 143-154. https://doi.org/10.1007/s13280-016-0816-3.

Kołodziej, B., Antonkiewicz, J., \& Sugier, D. (2016). Miscanthus $\times$ giganteus as a biomass feedstock grown on municipal sewage sludge. Industrial Crops and Products, 81, 72-82. https://doi.org/10.1016/j.indcrop.2015.11.052.

Korenblum, E., Dong, Y., Szymanski, J., Panda, S., Jozwiak, A., Massalha, H., Meir, S., Rogachev, I., \& Aharoni, A. (2020). Rhizosphere microbiome mediates systemic root metabolite exudation by root-to-root signaling. Proceedings of the National Academy of Sciences, 117(7), 3874-3883. https://doi.org/10.1073/pnas.1912130117. 
Kucharik, C. J., VanLoocke, A., Lenters, J. D., \& Motew, M. M. (2013). Miscanthus establishment and overwintering in the midwest USA: A regional modeling study of crop residue management on critical minimum soil temperatures. PLoS One, 8(7), e68847. https://doi.org/10.1371/journal.pone.0068847.

Kucharski, R., Sas-Nowosielska, A., Małkowski, E., Japenga, J., Kuperberg, J. M., Pogrzeba, M., \& Krzyżak, J. (2005). The use of indigenous plant species and calcium phosphate for the stabilization of highly metal-polluted sites in southern Poland. Plant and Soil, 273(1), 291-305. https://doi.org/10.1007/s11104-004-8068-6.

Lee, D. K., Aberle, E., Anderson, E. K., and 55 others (2018). Biomass production of herbaceous energy crops in the United States: Field trial results and yield potential maps from the multiyear regional feedstock partnership. GCB Bioenergy, 10(10), 698-716. https://doi.org/10.1111/gcbb.12493.

Lee, M.-S., Wycislo, A., Guo, J., Lee, D. K., \& Voigt, T. (2017). Nitrogen fertilization effects on biomass production and yield components of Miscanthus $\times$ giganteus. Frontiers in Plant Science, 8, 544. https://doi.org/10.3389/fpls.2017.00544.

Lehmann, J., Gaunt, J., \& Rondon, M. (2006). Bio-char sequestration in terrestrial ecosystems - A review. Mitigation and Adaptation Strategies for Global Change, 11(2), 403-427. https://doi.org/10.1007/s11027-005-9006-5.

Lehmann, J., Pereira da Silva, J., Steiner, C., Nehls, T., Zech, W., \& Glaser, B. (2003). Nutrient availability and leaching in an archaeological Anthrosol and a Ferralsol of the Central Amazon basin: Fertilizer, manure and charcoal amendments. Plant and Soil, 249(2), 343-357. https://doi.org/10.1023/a:1022833116184.

Liphadzi, M. S., Kirkham, M. B., \& Paulsen, G. M. (2006). Auxin-enhanced root growth for phytoremediation of sewage-sludge amended soil. Environmental Technology, 27(6), 695-704. https://doi.org/10.1080/09593332708618683.

Mamirova, A., Pidlisnyuk, V., Amirbekov, A., Ševců, A., Nurzhanova, A. (2020). Phytoremediation potential of Miscanthus sinensis And. in organochlorine pesticides contaminated soil amended by Tween 20 and Activated carbon. Environmental Science and Pollution Research. https://doi.org/10.1007/s11356-020-11609-y.

Mantineo, M., D’Agosta, G. M., Copani, V., Patanè, C., \& Cosentino, S. L. (2009). Biomass yield and energy balance of three perennial crops for energy use in the semi-arid Mediterranean environment. Field Crops Research, 114(2), 204-213. https://doi.org/10.1016/j.fcr.2009.07.020.

Matsuoka, S., Kennedy, A. J., dos Santos, E. G. D., Tomazela, A. L., \& Rubio, L. C. S. (2014). Energy cane: Its concept, development, characteristics, and prospects. Advances in Botany, 2014, 597275. https://doi.org/10.1155/2014/597275.

Maughan, M., Bollero, G., Lee, D. K., Darmody, R., Bonos, S., Cortese, L., Murphy, J., Gaussoin, R., Sousek, M., Williams, D., Williams, L., Miguez, F., \& Voigt, T. (2012). Miscanthus $\times$ giganteus productivity: The effects of management in different environments. GCB Bioenergy, 4(3), 253-265. https://doi. org/10.1111/j.1757-1707.2011.01144.x.

Mitros, T., Session, A. M., James, B. T., Wu, G. A., Belaffif, M. B., Clark, L. V., Shu, S., Dong, H., Barling, A., Holmes, J. R., Mattick, J. E., Bredeson, J. V., Liu, S., Farrar, K., Głowacka, K., Jeżowski, S., Barry, K., Chae, W. B., Juvik, J. A., ... Rokhsar, D. S. (2020). Genome biology of the paleotetraploid perennial biomass crop Miscanthus. Nature Communications, 11(1), 5442. https://doi.org/10.1038/s41467-020-18923-6.

Moberly Monitor. (2017). Miscanthus offers Missouri farmers use for marginal land. https:// www.moberlymonitor.com/news/20170502/Miscanthus-offers-missourifarmers-use-for-marginal-land. 
Moyer, J. (2017). Adaptability of Miscanthus cultivars for biomass production. Kansas Agricultural Experiment Station Research Reports, 3(2). https://doi. org/10.4148/2378-5977.1377.

National Corn Growers Association. (2019). National corn yield contest. https://www. ncga.com/get-involved/national-corn-yield-contest.

Nebeská, D., Pidlisnyuk, V., Stefanovska, T., Trögl, J., Shapoval, P., Popelka, J., Cerný, J., Medkow, A., Kvak, V., \& Malinská, H. (2019). Impact of plant growth regulators and soil properties on Miscanthus $\times$ giganteus biomass parameters and uptake of metals in military soils. Reviews on Environmental Health, 34(3), 283-291. https:// doi.org/10.1515/reveh-2018-0088.

Nielsen, P. (1990). Elefantengrassanbau in Dänemark-Praktikerbericht. Pflug Und Spaten, 3, 1-4.

Ouattara, M. S., Laurent, A., Barbu, C., Berthou, M., Borujerdi, E., Butier, A., Malvoisin, P., Romelot, D., \& Loyce, C. (2020). Effects of several establishment modes of Miscanthus $\times$ giganteus and Miscanthus sinensis on yields and yield trends. GCB Bioenergy, 12(7), 524-538. https://doi.org/10.1111/gcbb.12692.

Park, J.-W., \& Boyd, S. A. (1999). Sorption of Chlorobiphenyls in sediment-Water systems containing nonionic surfactants. Journal of Environmental Quality, 28(3), 945-952. https://doi.org/10.2134/jeq1999.00472425002800030027x.

Pidlisnyuk, V., \& Stefanovska, T. (2018). Methods for growing M. x giganteus at the abandoned land (Patent No. 127487), Ukraine.

Pidlisnyuk, V., Stefanovska, T., Lewis, E. E., Erickson, L. E., \& Davis, L. C. (2014). Miscanthus as a productive biofuel crop for phytoremediation. Critical Reviews in Plant Sciences, 33(1), 1-19. https://doi.org/10.1080/07352689.2014.8 47616.

Pillai, H. P. S., \& Kottekottil, J. (2016). Nano-phytotechnological remediation of endosulfan using zero valent iron nanoparticles. Journal of Environmental Protection, 7(5), 734. https://doi.org/10.4236/jep.2016.75066.

Pompeiano, A., Vita, F., Miele, S., \& Guglielminetti, L. (2015). Freeze tolerance and physiological changes during cold acclimation of giant reed [Arundo donax (L.)]. Grass and Forage Science, 70(1), 168-175. https://doi.org/10.1111/gfs.12097.

Ponomarenko, S. P., Hrytsaenko, Z. M., \& Tsygankova, V. A. (2013). Increase of plant resistance to diseases, pests and stresses with new biostimulants. Acta Horticulturae, 1009, 225-233. https://doi.org/10.17660/ActaHortic.2013.1009.27.

Ponomarenko, S. P., Stefanovska, T. R., Medkow, A. I., \& Kapriy, M. (2017). Bioregulators of plant development in growing biofuel crops. 17th International Scientific Conference Sakharov Readings: Environmental Problems of the XXI Century, II, 40-42.

Ponomarenko, S. P., Terek, O. I., Grytsaenko, Z. M., Babayants, O. V., Moiseeva, T. V., \& Wenxiu, H. (2010). Bioregulation of growth and development of plants: Plant growth regulators in crop science. In S. P. Ponomarenko \& H. O. Lutynska (Eds.), Bioregulation of Microbial-Plant Systems (pp. 251-291). Nichlava. Publishing Co., Kyiv, Ukraine, 472 pp. (in Russian).

Procházka, S., \& Šebánek, J. (1997). Plant Growth Regulators. Academia Publishing, Prague, Czech Republic. 395 pp., ISBN 80-200-0597-8. (in Czech).

Pude, R. (2008). Aktuelle Informationen aus der Miscanthus-Forschung. www.miscanthus.de. Pyter, R. J., Dohleman, F. G., \& Voigt, T. B. (2010). Effects of rhizome size, depth of planting and cold storage on Miscanthus $\times$ giganteus establishment in the Midwestern USA. Biomass and Bioenergy, 34(10), 1466-1470. https://doi. org/10.1016/j.biombioe.2010.04.014. 
Richter, G. M., Riche, A. B., Dailey, A. G., Gezan, S. A., \& Powlson, D. S. (2008). Is UK biofuel supply from Miscanthus water-limited? Soil Use and Management, 24(3), 235-245. https://doi.org/10.1111/j.1475-2743.2008.00156.x.

Roik, M., Sinchenko, V., Purkin, V., Kvak, V., \& Humentik, M. (Eds.). (2019). Miscanthus in Ukraine. FOP Yamchinskiy Press, Kyiv, Ukraine.

Sage, R. F., de Melo Peixoto, M., Friesen, P., \& Deen, B. (2015). C4 bioenergy crops for cool climates, with special emphasis on perennial C4 grasses. Journal of Experimental Botany, 66(14), 4195-4212. https://doi.org/10.1093/jxb/erv123.

Scagline, S., Skousen, J., \& Griggs, T. (2015). Switchgrass and miscanthus yields on reclaimed surface mines for bioenergy production. Journal American Society of Mining and Reclamation, 4, 80-90. https://doi.org/10.21000/jasmr15020080.

Schaap, M., Banzhaf, S., Scheuschner, T., Geupel, M., Hendriks, C., Kranenburg, R., Nagel, H.-D., Segers, A. J., von Schlutow, A., \& Wichink Kruit, R. (2017). Atmospheric nitrogen deposition to terrestrial ecosystems across Germany. Biogeosciences Discussions, 1-24.

Skousen, J., Keene, T., Marra, M., \& Gutta, B. (2013). Reclamation of mined land with switchgrass, Miscanthus, and Arundo for biofuel production. Journal American Society of Mining and Reclamation, 2,177-191.https://doi.org/10.21000/jasmr13010160.

Smith, L. L., Allen, D. J., \& Barney, J. N. (2015a). Yield potential and stand establishment for 20 candidate bioenergy feedstocks. Biomass and Bioenergy, 73, 145-154. https://doi.org/10.1016/j.biombioe.2014.12.015.

Smith, L. L., Askew, S. D., Hagood, E. S., \& Barney, J. N. (2015b). Screening preemergence and postemergence herbicides for safety in bioenergy crops. Weed Technology, 29(1), 135-146. https://doi.org/10.1614/wt-d-14-00100.1.

Song, J.-S., Lim, S.-H., Lim, Y., Nah, G., Lee, D., \& Kim, D.-S. (2016). Herbicide-based weed management in Miscanthus sacchariflorus. BioEnergy Research, 9(1), 326-334. https://doi.org/10.1007/s12155-015-9693-z.

Stewart, J. R., Toma, Y., Fernández, F. G., Nishiwaki, A., Yamada, T., \& Bollero, G. (2009). The ecology and agronomy of Miscanthus sinensis, a species important to bioenergy crop development, in its native range in Japan: A review. GCB Bioenergy, 1(2), 126-153. https://doi.org/10.1111/j.1757-1707.2009.01010.x.

Tabak, M., Lisowska, A., Filipek-Mazur, B., \& Antonkiewicz, J. (2020). The effect of amending soil with waste elemental sulfur on the availability of selected macroelements and heavy metals. Processes, 8(10), 1245. https://doi.org/10.3390/pr8101245.

Tian, H., Li, J., Mu, Z., Li, L., \& Hao, Z. (2009). Effect of pH on DDT degradation in aqueous solution using bimetallic $\mathrm{Ni} / \mathrm{Fe}$ nanoparticles. Separation and Purification Technology, 66(1), 84-89. https://doi.org/10.1016/j.seppur.2008.11.018.

Tomlinson, S., Carnell, E., Dore, A., Tipping, E., Misselbrook, T., Sutton, M., \& Dragosits, U. (2011). Historic nitrogen deposition: Long term trends [poster]. http://www.ltls. org.uk/sites/default/files/Historic\%20nitrogen\%20deposition_Tomlinson.pdf.

Tsygankova, V. A., Andrusevych, Y. V., Babayants, O. V., Ponomarenko, S. P., Medkov, A. I., \& Galkin, A. P. (2013b) Stimulation of plant immune protection against pathogenic fungi, pests and nematodes with growth regulators. Physiology and Biochemistry of Cultivated Plants, 45(2), 138-147 (in Ukrainian). https://www. academia.edu/4562192

Tsygankova, V. A., Yemets, A. I., Ponomarenko, S. P., Matvieieva, N. A., Chapkevich, S. E., \& Kuchuk, N. V. (2013a). Increase in the synthesis of polyfructan in the cultures of chicory "hairy roots" with plant natural growth regulators. International Journal of Biomedicine, 3(2), 139-144. https://www.elibrary.ru/item.asp?id=20250613. 
University of Iowa Facilities Management. (2020). Renewable energy. https://www. facilities.uiowa.edu/energy-environment/renewable-energy.

USDA/NRCS. (2011). Planting and managing giant Miscanthus as a bioenergy crop (Technical Note No. 4). USDA Natural Resources Conservation Service Plant Materials Program. https://www.nrcs.usda.gov/Internet/FSE_DOCUMENTS/ stelprdb1044768.pdf.

U.S. Environmental Protection Agency. (1994). A plain English guide to the EPA part 503 Biosolids Rule (EPA/832/R-93/003). Office of Wastewater Management, United States Environmental Protection Agency.

U.S. Environmental Protection Agency. (2019). Konza Prairie KNZ184. https://www3. epa.gov/castnet/site_pages/KNZ184.html.

White, J. C., \& Kottler, B. D. (2002). Citrate-mediated increase in the uptake of weathered 2,2-bis(p-chlorophenyl)1,1-dichloroethylene residues by plants. Environmental Toxicology and Chemistry, 21(3), 550-556. https://doi.org/10.1002/ etc. 5620210312.

White, J. C., Mattina, M. I., Lee, W.-Y., Eitzer, B. D., \& Iannucci-Berger, W. (2003). Role of organic acids in enhancing the desorption and uptake of weathered $p, p^{\prime}$-DDE by Cucurbita pepo. Environmental Pollution, 124(1), 71-80. https://doi.org/10.1016/ S0269-7491(02)00409-8.

White, J. C., Parrish, Z. D., Gent, M. P. N., Iannucci-Berger, W., Eitzer, B. D., Isleyen, M., \& Mattina, M. I. (2006). Soil amendments, plant age, and intercropping impact p,p'-DDE bioavailability to Cucurbita pepo. Journal of Environmental Quality, 35(4), 992-1000. https://doi.org/10.2134/jeq2005.0271.

Xue, S., Kalinina, O., \& Lewandowski, I. (2015). Present and future options for Miscanthus propagation and establishment. Renewable and Sustainable Energy Reviews, 49, 1233-1246. https://doi.org/10.1016/j.rser.2015.04.168.

Zeng, F., Chen, S., Miao, Y., Wu, F., \& Zhang, G. (2008). Changes of organic acid exudation and rhizosphere $\mathrm{pH}$ in rice plants under chromium stress. Environmental Pollution, 155(2), 284-289. https://doi.org/10.1016/j.envpol.2007.11.019.

Zinchenko, O. V. (2013). The evaluation of the effect of plants growth regulators on the photosynthesis intensity, survival rate and morphological indices of Miscanthus giganteus. Scientific Notices of the Institute of Energy Crops and Sugar Beets, 19, 47-51. http://www.bioenergy.gov.ua/sites/default/files/articles/47.pdf.

Zinchenko, O. V., Zinchenko, V. V., \& Ponomarenko, S. P. (2016). Environmental aspects of the cultivation of Giant Miscanthus, potato and oat. In V. V. Pidlisnyuk \& T. Stefanovska (Eds.), Phytotechnology with Biomass Production for Re-cultivation of Lands Contaminated and Damaged by Military Activities (pp. 102-105). Publisher house of NULES, Kyiv, Ukraine, ISBN 978-617-7396-14-6.

Zinchenko, V. O., Martynyuk, H. M., Zinchenko, O. V., Pitkevich, S., \& Wisniewski, G. (2009). Features of growth of Miscanthus $\times$ giganteus under radioactive contamination. The $V$ Scientific Conference for Students and Young Scientists, 138-140. Zhytomyr National Agroecological University, Zhytomyr, Ukraine (in Ukrainian). 